山階鳥研報 (J. Yamashina Inst. Ornith.), 18: 1-27, 1986

\title{
仲の神島の海鳥 類
}

\author{
河野裕美・安部直哉・真野徹
}

\section{The Seabirds of Nakanokami-shima, South Ryukyu, Japan}

\author{
Hiroyoshi Kohno*, Naoya Abe**, and Touru Mano***
}

\begin{abstract}
Nakanokami-shima was designated a national monument in 1972 because of its important for breeding seabirds, though the seabirds of the island were very poorly known. In this paper we present the information on the breeding species and their current status. Observations were made over a ten years period from 1975 to 1984 .
\end{abstract}

Seven species of seabirds were found to breed on the island. All were summer visitors, except for the Brown Booby which may be a resident.

1. Bulwer's Petrel, Bulweria bulwerii. Bulwer's Petrel was not known to breed on the island until we captured and ringed 2 adults on 2 July, 1981, both of which had fully grown brood patches, and 2 more adults on 4 July, 1982, both of which were incubating. In 1982, 1983, and 1984 the petrels bred at the same locations shown in Fig. 1. The petrels bred gathering in small numbers and laid under rock, Sixty-six adults were ringed from 1981 to 1984 and it seems that the breeding population is fewer than 100 birds.

2. White-faced (or Streaked) Shearwater, Calonectris leucomelas. Many nest holes of the White-faced Shearwaters were widely distributed on gentle slopes in grassplateau in the centre of the island. Some birds incubated on bare ground under dwarf 'Gajumaru', Ficus retusa, and others incubated under large rocks. We could not estimate their population.

3. Brown Booby, Sula leucogaster. The main colonies, which were used by almost all the birds, were found annually at areas A, B, C, and D shown in Fig. 2. On Nakanokami-shima Brown Boobies nested on ridges and on steep cliffs. Few birds nested in the rocky zone near the shore. Before noon on 3 July, 1981, a Maritime Safety Agency Helicopter flew over the eastern part of the island, surprising the settled birds and causing them to take flight one after another. It was possible at that time to make a total count and 250 birds were counted. Since the breeding pairs were taking care of chicks at that day, some parents were probably absent offshore. Clearly the population was larger than 250. A chick ringed on 29 June, 1980 , at the main colony was recaptured at the same place on 21 August, 1983. The bird was in adult plumage, but was not breeding. This recovery record indicates that non-breeding immatures are also included among those attending the main colonies. Table 1 shows the results of an intensive search for nests during the breeding season of 1984. Nests on inaccessible cliffs in areas A-D were of course

Received 7 January 1986

* Tokai University, Okinawa Regional Research Center, Sakiyama 165, Taketomi-cho, Yaeyamagun, Okinawa Prefecture, Japan 907-15.

** Asahi-cho 22-21, Sagamihara-shi, Kanagawa Prefecture, Japan 228.

*** Bird Migration Research Center, Yamashina Institute for Ornithology (Present Address: Kamiyashiki 33, Wakai-cho, Toyota-shi, Aichi Prefecture, Japan 470-12). 
omitted. The annual breeding population was estimated approximately as about 200 to 500 birds.

4. Red-footed Booby, Sula sula. This species was not known to breed in Japan before 1975, when we discovered a breeding pair on 27 August, 1975. The parent incubated one egg and its nest was builted on the canopy of dwarf 'Gajumaru' bush in area $\mathrm{A}$ in Fig. 2. On 24 June, 1976, 3 adults and 2 chicks were ringed at the same place, and on 30 June, 1977, one downy chick and parent were found again at the same place as in 1975. On 13 July, 1982, two fledglings and one adult were seen on the cliff in area $\mathrm{E}$ in Fig. 2.

5. Bridled Tern, Sterna anaethetus. This, species was not known to breed in Japan until we found its breeding at the island on June, 1980. The Bridled Tern settled rocky zone near the shore, placing their eggs in the shelter of rocks. The locations of colonies in 1983, and 1984 are shown in Fig. 3. This tern is apparently an inshore feeder, remaining usually close to the colony. The estimated numbers were 120 birds in area A, and 40 in area B on June 30, 1980, about 1000 in area A, and 100 in area B on 2 July, 1981, and about 650 in area, A, and 50 in area B on 2 July, 1982. Since 1981 the numbers have increased markedly. The birds in attendance at these areas were in adult plumage, however considerable numbers of non-breeding, presumably immature, birds may make up part of these totals.

6. Sooty Tern, Sterna fuscata. The locations of the colonies are shown in Fig. 4. Egg expoitation by Formosan fishermen occured in 1975, 1976, 1978, and 1979. Except for these years, the Sooty Tern formed a large colony on the open grassplateau at the centre of the island and was the most abundant breeding species. But it seems that the population is not so many as some authors said (600000 birds). Our estimates of total numbers in attendance during the daytime were: about 6400 adults in 1981, 4100 in 1982, and 3100 in 1983. As well known, this tern is offshore feeder; the feeding area of the tern breeding on Nakanokami-shima is not known.

7. Brown Noddy, Anous stolidus. This noddies laid on small niches, cliff, ledges, flat topped rocks, or beside rocks on gass-slopes. Virtually entire coast of the island is composed either of cliffs or rocky slopes, and the noddies nested along many parts of the coast. They prefered to settle at lower sites up to about $50 \mathrm{~m}$ above sea level, where they formed loose colonies. It was not possible to estimate their population because they were so widely dispersed. The Brown Noddy is probably the second most common breeder on the island.

8. The movements of these seven species and two further species of tern breeding on the Sakishima Archipelago, and the records of twelve other non-breeding seabirds are briefly described.

序

海鳥類の集団繁殖地として知られている八重山諸島の仲の神島は, 西表島の南西 $15 \mathrm{~km}$, お よそ北緯 24 度 11 分, 東経 123 度 34 分に位置している。この島は小さな孤島で, 東西方向 に細長く, 最大長約 $1550 \mathrm{~m}$, 最大幅約 $300 \mathrm{~m}$, 海抜 $102 \mathrm{~m}$ の無人島である。

この島の詳しい地形図はないので, 安部・真野 (1980) では, 国土地理院発行の 1/50000 地 形図を基に，本島の最大長を約 $1800 \mathrm{~m}$ と記述した。しかし，その後に発行された $1 / 25000$ 地 形困を基にすると，本島の最大長恃約 $1550 \mathrm{~m}$ になるので，本報で訂正した。さらに，島の中 央部西側の第 2 の高地の海抜は, 上述の $1 / 50000$ 図では $73 \mathrm{~m}$ であるが, $1 / 25000$ 図では $87 \mathrm{~m}$ に変更されているので，本報でもこの数值を用いた。 
Fig. 1 は上述の $1 / 25000$ 図を抎大して，現状に合わせて部分的に作図しなおしたものであ る。海抜 $102 \mathrm{~m}$ の最高地点から西方に海抜 $50 \mathrm{~m}$ に下る一帯には平坦な草地がひろがり，こ こょり西側の島の北面は草つきの急斜面である。海抜 $102 \mathrm{~m}$ 地点の東側の断崖下は, 南北海岸 線に通じる窪地状になっている。北面の大半部と南面のほぼ全域が断崖で, 海岸線のほ注全域 に大きな岩石の累積帯が続いている。上述の $1 / 25000$ 図では，本島周辺に珊瑚礁が発達してい るかのような記号があるが，実際は珊瑚礁の発達は乏しく，北側海岸線の中央部分から西側一 帯に長さ約 $400 \mathrm{~m}$, 最大幅約 $100 \mathrm{~m}$ 程度の珊瑚礁が発達しているのみである。

本島の植生を詳しく調査した文献はなく，著者等も未調査であり，不明な点が多い。樹木は ガジュマルのみで, 海抜 $102 \mathrm{~m}$ 地点の周辺に多いが, 強風により矮性化が著しく, 樹高は $2 \mathrm{~m}$ を越えず，多数の枝を複雑に横に伸ばし，地面を被うようにはえている。高良 (1970) は「草 本植物の主なものはボタンニンジン，八マナタマィ，メヒシバ，ツルナ，シマニシキソウ，、 マダイコン，ハママンネングサ，ハマボッスなど拈よそ20 種類。……とにばタンニンジン, ハマナタマメの生育が影著である。と記している。1978 年に本島を調查した藤岡 (1978) は 17 種の草本類を採集し,「黒島 (1964), 高良 (1970) はボタンニンジンが顕著に見られたと述 べているが，今回は全く認められなかった。」と報じている。

本島の中央台地に多いシバ類については, 高良 (1970) はメヒシバ, 藤岡 (1978) はハイシ バとソナレシバ，西村（河野宛私信，1985）はオヒシバをあげているように，草本類の各種の 生育状況は, 海象気象条件の影響を受汁やすい本島の環境下では, 年により著しい变化がみら れるようである。

なお, 本島の名称については, 上述の国土地理院発行の $1 / 50000$ 図では「仲の神島」とあり, ! $1 / 25000$ 図では「仲御神島」となっているが，本報では「仲の神島」を用いた。

仲の神島の海鳥類と人間のかかわりについては，古くは，魚釣島の開拓で知られる古賀辰四 郎氏が県の許可を得て, 明治 19 年 (1886 年) 3 月から本島で繁殖する海鳥類の羽毛ならびに 鳥翼の採取に着手し, さらに, 明治 42 年 (1909 年) には, 羽毛, 鳥䔬, 剥製, 鳥油, 海産物 等の採取事業を経営し，相当な利益をあげた（喜舎場 1953）。

抢そらく，比較的最近まで西表島，鳩間島，波照間島の住民が海鳥類の卵採取に渡島してい たようであるが，もちろん現在では日本人による卵採取は行われていない。

本島は海鳥類の集団繁殖地として 1967 年に琉球政府によって天然記念物に指定され, 同政 府が日本国に帰属後は，1972 年に日本国の天然記念物に指定されている。しかしながら，天 然記念物に指定後, 本島の海鳥類の保護対策が実施されているわけではない。大仲(1976), 山 階鳥類研究所・標識研究室 (1978), 安部・真野 (1980) にも記され, さらに本報でも述べる ように, つい数年前むで台湾漁師による海鳥類の大規模な卵採取が行われており, 現在でも容 与のならない状況である。

本島に棲息する海鳥類に関する知見はむしろ乏しく，著者等の調査も継続中で不充分なもの であるが，約 10 年間の調查結果をひとまず数篇にまとめて報告することにした。これらの報 文が本島の海鳥類の今後の保護策に役立てば幸である。

調 查 期 間

本報で述べる内容は次の（1）（2）の調査によって得たものである。 
（1）山階鳥類研究所・標識研究室は環境庁から受託した標識調査事業として下記の期日に 標識調査と併せて各種海鳥類の棲息状況調査を行った。

1975 年 8 月 27 日, 1976 年 6 月 23-25 日, 1977 年 6 月 28一30 日, 1978 年 7 月 1 一 3 日, 1979 年 7 月 $1-3$ 日, 1980 年 6 月 28 - 30 日, 1981 年 7 月 $1-3$ 日, 1982 年 7 月 $4,12-14$ 日。

（2）河野は1980 年から本島における標識調查に参加し, 以後, 勤務地の利を生かして, 特に 1982 年 3 月以来, 冬季間を除き注ぼ周年に渡島し, あるいは, 海上で調査を行った。本 島に上陸して調査した期日は次のとおりである。

1982 年 7 月 4,12 - 14,19 日， 8 月 $18 ， 19 ， 22 ， 23 ， 29,30$ 日， 9 月 29 日， 10 月 11 , 21 日。 1983 年 5 月 25 日， 6 月 8,11 日， 7 月 $12,19,20,28$ 日, 8 月 2, 3, 8, 21, $22,29,30$ 日, 9 月 1,2 日, 10 月 17,19 日, 11 月 8,10 日, 12 月 13 日。 1984 年 3 月 30 日, 4 月 20,26 日, 5 月 10,26 日, 6 月 $4,8,9,13,14,19,20,29,30$ 日, 7 月 $6,11,12,14,15,19,20,22,23$ 日, 8 月 $11,12,23,24$ 日, 9 月 $6,7,11,12$, 27 日, 10 月 17 日, 12 月 14 日。

これまでの本鳥の海鳥類調查は，いずれも短期間の断片的なものであったが，上記 (1)， の調査によって, 繁殖鳥の渡来から渡去までの繁殖の進行状況に関する知見がかなり得られた。

\section{調 查 結 果}

仲の神島および周辺海域に棲息する海鳥類について，初めに繁殖鳥について述へ，次に非繁 殖鳥について述べた。

\section{繁殖鳥とその棲息状況}

本島で繁殖していた海鳥は 7 種で, このらちの 3 種は著者等が繁殖種として新しく追加でき たものである。以下，各種の棲息状況を分類系列順に記した。

\section{1. アナドリ Bulweria bulwerii}

営巣地域, 環境, 繁殖個体数 1981 年 7 月 2 日に本種の成鳥 2 羽を初めて発見し, 下記 のように捕獲, 標識した。7 月 2 日の 23 時頃, 海抜 $102 \mathrm{~m}$ の最高部の南東, 少し下方のカッ オドリの営巣地域で調査中に, 急斜面の岩場の岩上に休む 1 羽を, さらに, 10 数 $\mathrm{m}$ 離れた岩 上に休む他の 1 羽を同時に発見し，この 2 羽を捕獲標識した。この 2 羽は成鳥で, 下腹部によ く発達した抱卵斑が 1 つ認められたので，この付近で繁殖中と推察された。しかし同年の調査 は翌日で終了し離島したので，その卵，雛は捜し出せなかった。

1982 年には 7 月 4 日に第 1 回調査を行った。同日は日中数時間の上陸調査であったが，前 年に本種を 2 羽捕獲した同じ岩場を調査したところ, 平らな岩の下の穴状部で抱卵中の 2 羽を 約 $40 \mathrm{~cm}$ 離れた 2 個所で発見した。この 2 羽は前年に標識した個体ではなかった。抱卵数はい ずれも 1 泗で，その 1 卵は純白，他の 1 卵は全体に淡い褐色を帯びていた。

同年の第 2 回調査は 7 月 12-14 日に行った。7 月 13 日の日中にこの 2 羽を調査したとこ ろ, 順調に抱卵中であった。しかし，河野・安部・真野 (1986) で述べた台風 8211 号の被害 で,この 2 巣とも繁殖成功に至らなかった。

1982 年より本種の営巣場所の探索に努め, 主な集団営巣地之繁殖状況について次のような 


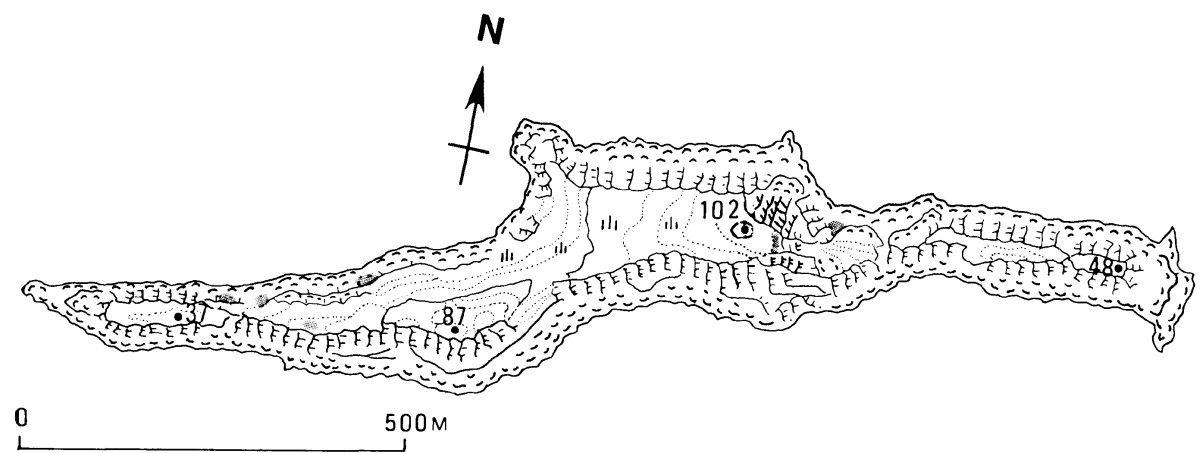

Fig. 1. Map of Nakanokami-shima. This island is situated at $24^{\circ} 11^{\prime} \mathrm{N}, 123^{\circ} 34^{\prime} \mathrm{E}, 15 \mathrm{~km}$ SW of Iriomote-jima, the Sakishima Archipelago, South Ryukyu. Gajumaru, Ficus retusa, which is only one tree there, is colonized near the peak of $102 \mathrm{~m}$ and is dwarfed up to two metres. The centre of island is a open grass-plateau. Steep cliffs surround most parts of island; the shore is zone of large rocks. The shaded areas are colonies of the Bulwer's Petrels in 1982, 1983, and 1984. In these years the petrels bred at same locations.

知見が得られた。1982 年から 1984 年に, 本島の海岸線全域と稜線部を主として 22 時から 03 時の夜間に 12 回踏査して得た本種の営巣場所を Fig. 1 に示した。ミズナギドリ科の本種は, 同科の他の種と同様，繁殖期には営巣場所でその姿が日中観察されることはほとんどない。従 って, 夜間に営巣場所の岩上で休んでいる個体や岩の陣間に見える個体の発見, さらに，岩の 下から聴こえてくる「ウッウッウッウォッ, ウッウッウッウォッ」といら鳴声を手がかりに営 巣場所を捜し出した。また，岩上に 1 羽を発見した場合，その周囲をへッドライトで照して待 機していると，他の個体も岩の奥から出てくる場合も多かった。

Fig. 1 に示したように, 本種のどの営巣地もその規模は小さく, 1981 年から 1984 年にこ れらの営巣地で捕獲標識できた成鳥数は 66 羽しかなく, 1 営巣地域での成鳥の捕獲数は稜線 部のそれでは 2 羽か 3 羽, 海岸線のそれでは5-15 羽であった。そして, 海岸線にあった最大 の営巣地でも約 $16 \mathrm{~m}^{2}$ にすぎなかった。

前述の 66 羽の標識鳥のうち 2 羽は，翌年の繁殖期に同じ場所で再捕獲され，1982，83，84 年の本種の営巣場所はほ湆同じ地域に形成されていた。以上のことから判断すると, 本島に打 汀るアナドリの繁殖個体数は多くても100 羽程度であろう。

Berger (1972) によると，八ワイ諸島で繁殖する本種の営巣場所は島によってかなり異なり， 岩の下, 崖地の岩の間の奥, 地中の穴, 珊瑚塊の下, 上く繁茂している草木の陰などに白色の 1 卵を産卵している。そして, 前述のように, 八ワイ諸島でも夜間に営巣場所の近くに出て休 んでいる成鳥がよく観察されている。

仲の神島における本種の海岸線の営巣地はマミジロアジサシの営巣地域の内部にあり, 稜線 部の営巣地はカツオドリの営巣地とも一部重複している。本島のマミジロアジサンも岩の間か 岩の下に産卵しているが，その卵は外から比較的見兄やすいのに対し，アナドリはその名前が 示すように，前種よりも，さらに奥深い岩の陌間や岩の下に産卵することが多く，その卵や雛， 抱卵中の成鳥を捜し出すのは容易でない。本種はほとんど巣材を用いず，1 卵を産卵する。 
河野裕美・安部直哉・真野 徹

仲の神島で観察された本種の営巣場所の環境, 営巣地の規模などは, 他の地域における知見 (Cramp, S., and KEL Simmons edt. 1977) と異なるところはない。

渡来から渡去までの概況前述の 66 羽の成鳥の捕獲日, 9 卵と 3 雛の観察日, 周年の海 上観察などから本種の仲の神島における渡来から繁殖, 渡去までの概況は次のようである。 仲の神島一西表島間の海上での本種の初認日は 4 月下旬から 5 月上旬であるから，仲の神島 周辺への渡来期はこの頃であろう。島への定着期と思われる頃の捕獲例として, 1983 年 6 月 11 日に 2 羽, 1984 年 6 月 13 日に 4 羽の成鳥を営巣地域で捕獲したが, これら 6 羽ともに抱 卵斑は未発達であった。これらの個体が繁殖に入る直前の段階のものか, それとも未繁殖の若 龄鳥かは明らかにできなかった。抱卵斑の発達した成鳥を捕獲できた早期の例と卵を発見した 例は, 前述の 1981 年 7 月 2 日の 2 羽, 1982 年 7 月 4,13 日に抱卵中の同じ個体 2 羽, 1983 年 7 月 12 日に 1 卵，1984 年 6 月 19 日に 6 卵，7 月 14，15 日に 2 卵の事例である。なお本種 の抱卵日数については資料がそしく, Shelton (Cramp, S., and KEL Simmons edt. 1977 よ り）による，44 日と 47 日という2 例の記録がある。本島のアナドリについては, 抱卵日数を 確かめられなかった。

本島のアナドリの篗の初めての発見は, 1983 年 7 月 28 日の 1 羽で, 続いて 8 月 2,3 日に も2 雛を発見した。いずれも，黑い綿羽に被われた初期の雛であった。本種の餒化から幼羽が はえそろうまでの日数は, Shelton (同上)によるJohnston Atoll における8 例では 57一67日 である (Fig. 5-A)。

営巣中の本種の成鳥は, 夜間に帰島し, 早朝明かるくなる前に海上に出て採食している。繁 殖期には，西表島西端の八重目崎と仲の神島間で，日中に海上低くを飛行する本種が稀ならず 観察され, 多くの場合に 1 羽ずつ飛行している。繁殖期の本種の採食海域は, 営巣地の仲の神 島からあまり離れていない海域と思われる。八重目崎一仲の神島間の航路で本種が比較的多く 観察された記録を示すと次のようであった。1982 年 7 月 4 日, 11 時 12 分一13 時 28 分に計 17 羽, 16 時 5 分一 17 時 0 分に計 20 羽。 1983 年 7 月 12 日, 16 時 0 分一 18 時 46 分に計 10 羽。 8 月 8 日, 10 時 10 分一 11 時 0 分に計 7 羽。 16 時 0 分一 50 分に計 15 羽。1984 年 6 月 13 日, 16 時 50 分一 18 時 30 分に計 6 羽。 7 月 11 日, 17 時 45 分一 18 時 35 分に計 8 羽。

これまでの海上における終認日の最もおそい例は1982 年 10 月 11 日であった。1984 年 10 月 19 日には営巣地域にも本種は棲息せず，海上にも観察できなかった。本種は10月中旬頃には 仲の神島抢よび近海から去るようである。

仲の神島に近い本種の繁殖地は台湾之福建省沿岸の島々（鄭作新 1976）で，台北沖の綿花 島（小川 1906）尖閣諸島の黄尾島（宮島 1900）からの記録もある。八重山諸島には，本種の 繁殖の可能性がある島が他にもあり，今後調査の予定である。

\section{2. オオミズナギドリ Calonectris leucomelas}

営栄地域と環境本種は島の高部平坦地と稜線部から北に面した斜面一带, 海抜 5-102 m までの草つきの傾斜地のほぼ全域に営巣している。主な営巣地域は高部平坦地とそれに続く傾 斜地の草地にあり, 地下に横穴を掘って営巣している。しかし, 海抜 $102 \mathrm{~m}$ 付近にある矮性化 したガジュマル群生地では樹下の地表にそのまま産卵するものもあり，また，草つきの急斜面 の岩場や海岸に近い転石帯では岩陰に産卵するものも少数ある。

渡来から渡去までの概況本島のオオミズナギドリの繁殖進行状況や棲息数については詳 
しい調査を行えなかったので確かな知見はない。

早期の海上での記録として, 1982 年 3 月 11 日に石垣島の南東沖 $25^{\circ} 09.7^{\prime} \mathrm{N}, 124^{\circ} 42.5^{\prime} \mathrm{E}$, 水深 $2000 \mathrm{~m}$ の海域で観測中の東海大学丸II世 (702 t $)$ により，数 10 羽の本種の群が観察さ れている(澤本 1983，河野宛私信）。

1983 年の第 1 回渡島調査を行った 3 月 30 日の日中には, 高部平坦地の多くの巣穴では土が 掘り出され，巣穴修復の形跡があった。そのらち4 巣の内部からピーピーといら成鳥の鳴声が 聴かれ，また，2 巣では巣穴に頭部から胸部までを入れたまま死んでいる成鳥 2 羽が発見され た。その 1 羽の死体はまだ新しく，他の 1 羽は頭部の腐敗が進んでいた。

1984 年には, 夜間調査中，5月 26 日に巣外で成鳥数羽を観察したが，巣穴内からの鳴声は 聴かれなかった。6月 8 日には，巣外での交尾を観察し，さらに，交尾時に発するのと同じ雄 の特徵的な鳴声が多数の巣穴内から聴かれた。

1975 年以来の 6 月末一 7 月上旬にお汀る標識調査中の観察から, この頃, 大部分の番が抱卵 中と推察される。1984 年 9 月 11 日には, 綿羽雛 31 羽に標識した。1982 年 10 月 11 日には, 人が近寄ると，かららじて飛行することのできる成長段階の幼鳥 5 羽が観察された。

晚期の観察例としては, 1982 年 10 月 30 日一-31 日に西表島西部の外離島沖から八重目崎, 黒島沖にかけて銀河 II世 $(6.02 \mathrm{t})$ で海洋観測中に，10月30日 15 時頃，八重目崎の北 $1.5 \mathrm{~km}$ の海域を仲の神島方向に飛行中の 4 羽を観察している。1983 年 10 月 19 日には, 高部平坦地 の主集団営巣地に巣外に出る時期の近い幼鳥が多数棲息していたが，成鳥は夜間の営巣地にも 海上にも観察できなかった。同年 11 月 10 日には，主集団営巣地に幼鳥の姿はすでになかった。 そして, 頭部から背面の羽毛先端部が白く, 細いまだら模様の顕著な幼鳥 3 羽を八重目崎一仲 の神島間の海上で観察した。これが最もおそい終認記録である。

ただし，本種は日本沿岸に多くの繁殖地があるので，上述の海上での記録が仲の神島で繁殖 する本種と直接関連があるとはいえないが，本種は 11 月上旬頃には仲の神島近海から渡去す るよらである。

\section{3. カッオドリ Sula leucogaster}

営巣地域と環境本種の営巣地域を Fig. 2 に示した。これらの営巣地域の位置は毎年ほ とんど变化がなく, 主要な営巣地は海抜 $102 \mathrm{~m}$ の最高地点より東側の稜線周辺と急斜面一帯で ある (Fig. 2 の地区 A，B)。しかし，海抜 $87 \mathrm{~m}$ 地点の西側に続く同様の場所あるいは断崖の 岩棚 (Fig. 2 の地区 E, F) に数番が営巣したこともある。営巣地域の海抜は 10 - $90 \mathrm{~m}$ にわ

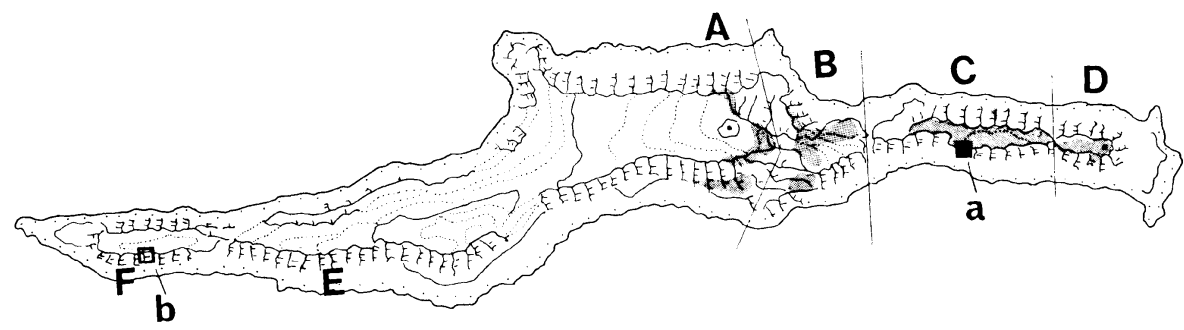

Fig. 2. Colonies of the Brown Boobies, which nested usually areas A, B, C, and D. Few pairs settled in area $\mathrm{E}$ or $\mathrm{F}$ occasionally. 
たっているが，断崖上縁部に近い所で営巣する個体が多く，本島では汀線に近い岩石累積帯や 斜面下部での営巣数はきわめて少ない。

渡来から渡去之非繁殖期の概況仲の神島近海の $1 ， 2$ 月の海洋気象条件は北寄りの強風 が優勢で荒天時化が多く，本島への渡島が困難なので調査は行っていない。

1984 年の調査によれば，第 1 回渡島調査を行った 3 月 30 日には，Fig. 2 の地区 A では 1 卵か 2 卵の巣が多く，また，成鳥が巣についているが卵のない巣も観察された。

4 月 20 日と 26 日の地区 $\mathrm{A}$ では，白い綿羽で被われる前の成長段階の 1 雛 1 卵の巣が多く, 2 雛のいる巣も 1 例あった。

5 月 10 日の地区 $\mathrm{A}$ では，調査した 16 巣中， 1 卵が 1 巣， 2 卵が 5 巣， 1 雛 1 卵が 3 巣, 1 雛が 7 巣であった。

5 月 26 日には，地区 $\mathrm{A}-\mathrm{D}$ にあった抱卵ないし育雛初期の 102 巣の卵および篗数は Table 1 のようであった。1 雛の巣の産卵数は 1 卵， 1 卵之初期雛 1 羽の巣の産卵数は 2 卵と仮定す ると， 1 腹 1 卵の巣は 76 例， 1 腹 2 卵の巣は 25 例， 1 腹 3 卵の巣は 1 例となる。 1 腹 2 卵

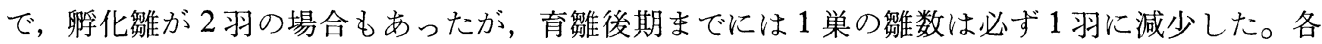
年の食糧条件によって，本種の育敭期間や雛の独立までの期間に変化が生じることは，外国で の本種の研究でよく知られているが，本島のカッオドリについては確かな資料は得られていな い。

幼鳥は 10 月中までには海上生活に入り，島には酒とんど見られなくなる。しかし成鳥は 12 月以後も仲の神島で観察されている。その羽数は年により異なり，1983 年 12 月 13 日には, Fig. 2 に示す $\mathrm{a}$ 地点に成鳥約 100 羽， b 地点に成鳥約 50 羽と幼鳥 5 羽，1984 年 12 月 14 日に は，a 地点だけに成鳥約 30 羽が観察された。非繁殖期にカッオドリが営巣地域を離れて，上 述の $\mathrm{a}, \mathrm{b}$ 地点のように本島の南向きの断崖に集まっているのは，北寄りの風が卓越する冬期の 気象条件（石丸 1980）を避けているのであろう。

本種が 1 月， 2 月にも仲の神島およびその近海に棲息しているのかどらかは明らかでないが， 1977 年から 1984 年までに標識した 272 羽の幼鳥のらち，1979 年 7 月 1 日に標識された幼鳥が 同年 10 月 15 日にフィリピンのルソン島南部のラモン湾で回収されている (山階鳥研, 標識研 究室 1980)。

成鳥の個体数＼cjkstart本島で繁殖するカツオドリの個体数の算定は，その営巣地が断崖上縁部の

Table 1. Breeding status of the Brown Booby on 26 May, 1984.

\begin{tabular}{lrrrrr}
\hline \hline \multirow{2}{*}{ Nest contents } & \multicolumn{3}{c}{ Area } & Total \\
\cline { 2 - 5 } & A & B & C & D & \\
\hline 1 egg & 1 & 4 & 1 & 0 & 6 \\
2 eggs & 4 & 9 & 3 & 3 & 19 \\
3 eggs & 0 & 1 & 0 & 0 & 1 \\
1 egg and 1 chick & 3 & 2 & 1 & 0 & 6 \\
1 chick & 17 & 35 & 13 & 5 & 70 \\
2 chick & 0 & 0 & 0 & 0 & 0 \\
\hline & 25 & 51 & 18 & 8 & 102
\end{tabular}

Notes. (1) Areas are shown in Fig. 2 in text. (2) Out of 102 nests, 76 nests are clutch one. 
ほかに断崖の岩棚にもあるので，きわめて困難である。次に記すように，1981 年には幸い Fig. 2 の地区 $\mathrm{A}$ 一D に日中留まっていた成鳥の概数を推定する機会が得られた。

1981 年 7 月 3 日の正午前, 地区 A の崖地上縁部で観察中に海上保安庁のへリコプターが石 垣島方向から飛来し，本島の東端上空から西方に向けて低空を巡回飛行した。これに驚いた地 区 A一Dのカツオドリは続々と断崖から飛び立ち, 北側上空に出て,すぐ一群をなして付近を 5, 6 分間旋回後, 群を解いて順々に崖地に戻った。この時, 全飛行個体を写真で記録でき, その総羽数は 251 羽であった。この間, 視野外の崖地に残っていたカツオドリの数は不明であ るが，ヘリコプターに驚いて飛び立った様子や一群になった後に，また崖地に戻る状態などか ら，上述の 251 羽は地区 A-D の成鳥のほぼ全個体に近いだろらと推察された。この時期は, おそらく大部分の番が育雛期に入っていたと思われ，沖合に採食に出ていた親鳥の数は全く不 明である。さらに，1980 年 6 月 29 日に標識した幼鳥が，1983 年 8 月 21 日に地区 A で再捕獲 されており，この個体は顔の黄色い成鳥羽であったが，繁殖は行っていなかった。この例か ら, 上述の 251 羽の総てが繁殖鳥であるとは断定できない。近年の本種の繁殖個体数は, およ そ200-500 羽程度であろら。

雌雄の顔の色彩カッオドリの成鳥の顔部の皮膚の色彩は, 雌雄によって異なり, また, 繁殖個体群間にも多少の相異がある (S. Cramp and KEL Simmons edt. 1977)。本島で繁殖 するカッオドリでは, この部分の色彩が淡い粉青色の個体と淡い粉黄色の個体があり, 前者が 雄で, 後者が雌と思われる。

\section{4. アカアシカッオドリ Sula sula}

本種は熱帯, 亜熱帯の海洋に広く分布, 繁殖している。日本に拈ける分布については, 日本 鳥学会編（1974）『日本鳥類目録』改訂第 5 版の英文版では「小笠原諸島 (西之島)，硫黄列島 (北硫黄島), 南鳥島」に記録があると記述されている。一方，その和文版では，上記のほかに， 「南部琉球」を加兄て，「ごく稀に渡来するにすぎない」と記述されている。

著者等の調べた限り，同目録が出版されるまでの文献で本種の南部琉球での分布を記したも のはない。おそらく，和文版編集委員の未発表の資料か，大仲 (1982) の「1973 年5月3031日, アオッラカッオドリ，アカアシカッオドリの繁殖確認」といら情報を編集委員が当時入 手して加筆したものと想像される。ただし，大仲 (1982) は，上記 2 種の繁殖状態について全 く記述していない*。

著者等による仲の神島にお忷る本種の卵，雛（幼鳥）の発見を含む観察結果は次のとおりで ある。

成鳥の羽色型について 本種成鳥の羽色には, 白色型, 褐色型, その中閒型の 3 型が知ら れている。著者等が仲の神島で観察した成鳥の羽色型は, 1980 年 6 月 28一30 日に観察した中 間型の亜成鳥かと思われる 1 羽を除き，他の個体は白色型であった。

各年の棲息状況と繁殖記録 1975 年 8 月 27 日, 海抜 $102 \mathrm{~m}$ の最高地点より西へ少し下っ

* 1973 年 5 月 30-31 日のアカアシカツオドリとアオッラカッオドリの棲息状況について大仲氏に問

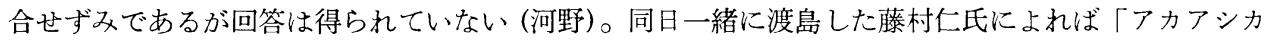
ツオドリと同定した成鳥 1 羽が島から飛びたったのを観察しただけで，アオッラカツオドリは観察さ れていないので, 両種の繁殖確認という大仲氏の記述は, 同氏の別の機会の調査結果との混同かもし れない」(安部宛私信) とのことである。 
た南側崖の上縁部に群生する矮性化した高さ約 $2 \mathrm{~m}$ のガジュマルの樹冠上に枯枝を組み合わせ て作ってある, 直径約 $50 \mathrm{~cm}$ の本種の巣と白色の 1 卵を発見した。親鳥は抱卵中であったが, 巣があることに気付かずに接近したため, 親鳥は巣を離れ，飛び去ってしまった。猛暑の日中 であったので，強い直射光が卵に与える悪影響を配慮して，その巣と卵，環境の記録撮影をす ぐ済ませて，その場を離れた。同年の調査は 8 月 27 日だけであったが，本種の繁殖記録が初 めて得られた。

1976 年 6 月 24 日には，前年と同じ場所の群生するガジュマル上に成鳥 3 羽と幼鳥 2 羽を目 撃し, 同日夜間に成鳥 2 羽と幼鳥 2 羽を捕獲し標識した。その場所に本種の巣は見られなかっ たが，群生するガジュマルの樹冠部の葉が無くなっている所が数個所あり，枝はむき出しにな り，周辺は鳥粪で真白になっていた。

1977 年 6 月 30 日には, 1975 年と同じ場所の同じ個所に 1 番が営巣していた。この巣に注意 深く接近したが，親鳥は間もなく巣から飛び立ち，上空を飛びまわり警戒した。その巣には， 餒化後 1-2 週間汪どの白色の綿羽に被われた雛 1 羽がいたので，雛と巣の記録撮影を済ませ て，その場を離れた。6月28一30日の調查中に，最大 8 羽の成鳥を観察したが，他の巣は発 見できなかった。

1980 年 6 月 28-30 日には，本種の中間型亚成鳥と思れれる 1 羽が，海拔 $102 \mathrm{~m}$ 地点の南側 断崖に着陸を試るように付近をよく飛行していたが，巣も他の個体も観察できなかった。

1982 年 7 月 13 日には, 海抜 $87 \mathrm{~m}$ 地点からおよそ $120 \mathrm{~m}$ 注ど西方, 南側断崖の岩棚にはえ る矮性化した高さ $1 \mathrm{~m}$ 以下のガジュマルにとまったり，その付近を数 $10 \mathrm{~m}$ 飛んでは戻る幼鳥 2 羽と成鳥 1 羽が観察された。その付近には鳥糞で污れた所もなく，また，海抜 $102 \mathrm{~m}$ 地点付 近のガジュマル群生地にも, 本種が営巣したと思われる所はなかったの, 著者等の気付かなか った別の場所で営巣し，この付近に移って来たのであろう。

この幼鳥 2 羽の羽色は, 全体に少し灰色を带びた淡褐色で, 頭部から背面に淡黄褐色の縦斑 が散在していた。前述の 1976 年 6 月 24 日に標識した 2 羽の幼鳥の羽色は, 頭部から体の上面 は淡褐色で 1980 年の上述の幼鳥に近く, 体下面は白色であった。この 2 羽の成長段階は, 1980 年の幼鳥の前の段階のもので，やがて体下面も褐色羽に変化するのであろう。これら4羽の幼 鳥の脚の色は, いずれも，淡い桃色であった。

5. マミジロアジサシ Sterna anaethetus

本種の日本に抢ける繁殖は, 1980 年の調査中に本島で初めて発見され（安部・真野 1980), その後, 1981 年に宮古島北方のフデ岩と同島東南部の軍艦島でも本種の繁殖が確かめられた (安部 他 1982)。

営巣地域と環境本種は大きな岩が累積している環境の岩と岩の隚間や岩陰に主に産卵し ている。仲の神島の海岸線のほぼ全域にこのような岩石累積带があり, 本種の 1983 年と 1984 年の営巣地域を Fig. 3 に示した。棲息数は地区 A と C に多く, 汀線より約 $10-30 \mathrm{~m}$ 離れ た海抜 3-10 m の範囲に集団営巣地が形成されている。Fig. 3 には示してないが，たとえば， 地区 A の上部に続く海抜 40一5 $\mathrm{m}$ の草付きの急斜面の岩場や稜線部の岩場のような環境にも 少数だが営巣している。

1980 年の営巣地の規模は，1983，1984 年にくらべて，はるかに小さく，地区 A の一部と地 区 D の一部に限られていたが (安部・真野 1980), 1981 年以後, 地区 A の営巣地は 1983, 


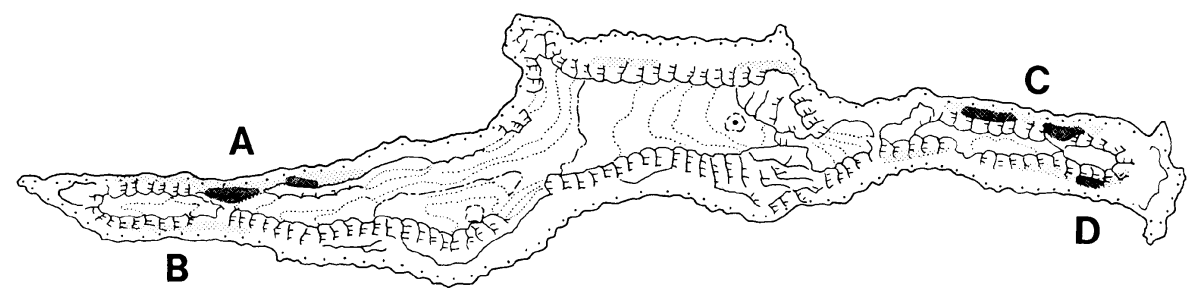

Fig. 3. Colonies of the Bridled Terns in 1983, and 1984. In these years the terns bred at the same areas.

Table 2. Numbers of the Bridled Tern's egg and chick found in area A on the season of 1984 .

\begin{tabular}{lcccccc}
\hline \hline & 10 May & 13 June & 19 June & 29 June & 7 July & 19 July \\
\hline Egg & 2 & 40 & 50 & 22 & 10 & 4 \\
Chick & 0 & 1 & 3 & 17 & 18 & $4 \ldots$ Total 43 \\
\hline
\end{tabular}

Note. Each egg was not marked, while all chicks were ringed in each day.

1984 年とほぼ同じ規模に払大した。

渡来から渡去までの概況 1984 年の調査から本種の渡来から渡去までの状況を以下に記 した。4 月中旬頃, 西表島一仲の神島間や西表島西部の沖合約 $10 \mathrm{~km}$ の海域に, クロアジサ ンの群に混じって採食する本種が観察されるようになる。この時期の日中の渡島調査を 4 月 26 日に行ったが, 営巣地となる岩石累積帯に着陸している個体はなく, その付近を飛んでいる個 体も観察されなかった。営巣地域への定着状況や時期は明らかでない。

Fig. 3 の地区 A に打汀る5 月から 7 月の調査中に捜し出した本種の卵数と雛数を Table 2 に示した。なお，Table 2 に記した卵は個々に標識して区別されていない。雛数は各調査日に 新しく標識した羽数のみを記してある。

本種の雛は，日中，親鳥が飛び立って発する警戒声を聴くと岩と岩の隙間の奥にすぐ隠れる ので捜しにくいが，夜間は日中にくらべて警戒性が弱く，雛を捜しやすいので，22 時一03 時 の夜間にも調査を行った。

5 月 10 日には，4 月 26 日と同样に，営巣地の岩上にとまっている個体も付近を飛んでいる 個体も観察されなかった。しかし，岩の吵間にうずくまっている成鳥 5 羽が観察され，そのう ちの 2 羽はそれぞれ 1 卵を抱卵中であった。他の 3 羽は抱卵しておらず，まだ産卵していない と思われた。なお，本種の 1 腹卵数は 1 卵である。

6 月 13 日には，捜し出せた 41 巣は 1 卵 40 巣と餒化後間もない 1 雛 1 巣， 6 月 19 日には 50 卵と 3 雛，6月 29 日には 22 卵と 17 雛，7 月 7 日には 10 畉と 18 雛， 7 月 19 日には 4 卵と 4 雛であった。

本島のマミジロアジサジについては抱卵日数も育雊日数も確かめられなかった。 K. Hulsman, Hulsman (1974, 1977), Diamond (1976) によると, 本種の抱卵日数は 28-30日, 餒化 後, 幼羽がはえそろらまでの日数は55-63 日, その後さらに約 35 日で営巣地を離れる例もあ る (以上, S. Cramp edt. 1985 より引用)。この知見と上述の調査結果からすると, 本種の 
1984 年の産卵期はおよそ 5 月中旬から 6 月上旬のようである。

9 月上旬には岩石累積帯に多くの幼鳥が観察されたが，9月中旬に幼鳥，成鳥とも島を離れ た。地区 A において，片翼が折れて療着し，飛行できない幼鳥 1 羽が 9 月 27 日に観察されて いるが，これは例外である。同日，本島の北方約 $1 \mathrm{~km}$ の海上に浮遊する $30 \mathrm{~cm}$ 注どの木片に おりている成鳥 2 羽が観察された。これが本種の最もおそい終認記録である。

雛および幼鳥の羽色型について 1984 年 5 月から 9 月の調査中に，綿羽雛から飛行でき る成長段階の幼鳥まで計 126 羽に標識した。その調査中に次のような羽色型が見られた。つま り，綿羽雛には暗色型と淡色型があった。幼羽のはえそろった幼鳥には，(1) 背部，翼上面が 一様に淡い灰褐色の個体，(2) 背面と雨覆の羽縁が灰白色の個体，(3) 同じ部分の羽縁が赤褐 色の個体，(4) (2) と（3）の中間色の個体が区別された。これらの羽色型については別に報告す る (Fig. 5-E)。

成鳥の個体数 マミジロアジサシは沿岸採食性で, 繁殖期中, 本島から数 $\mathrm{km}$ 以内で日中 に採食している状況がよく観察される。しかし，夜間に採食に出ているかどうかは明らかでな い。日中は，営巣地域の岩石累積帯とその周辺からほとんど離れずに生活しているが，累積す る岩石の陰に隠れている鳥の姿は見えにくいので，成鳥の個体数を算定するのは容易でない。 そこで，調査者が営巣地内を歩いて鳥を飛び立たせ，飛行中の個体数をかぞえてみた。

1980 年の成鳥の個体数は少く, Fig. 3 の地区 A の一部に約 120 羽, 地区 D の一部に約 40 羽，地区 A と B の間の稜線部に数羽が棲息していた程度だった（安部・真野 1980）。

1981 年の繁殖期には，安部 他 (1982) でも簡単に記したように地区 A, B の成鳥の個体数は 前年よりはるかに増加し，特に地区 A と B は，前述のように 1983，1984 年とほぼ同じ規模に 拡大していた。7 月 2 日，地区 A， B に定着している成鳥の個体数調查を次のように行った。 同日には, 繁殖鳥の大部分は抱卵期であった。長さ約 $600 \mathrm{~m}$ の地区 A をよく目立つ大岩と地 形を目印にして，およそ 3 等分し，各区分ごとの成鳥数を計数した。調查者の 2 人が地区 $\mathrm{A}$ 内 を東端から西端に向って初めの $200 \mathrm{~m}$ 間を一緒に歩き, 以後は調查者 1 人が先に進み，別の 1 人は約 50-100 m 後方を進んで, 先行者の進入によって飛び立って営巣地上を飛行する個体数 を後続の調查者が計数した。約 1 時間後に，再度調查者 1 人で地区 $\mathrm{A}$ 西から東に歩るいて同 様に成鳥数をかぞえた。その結果は，およそ 3 等分した各区分に，東から西にそれぞれ約 300 羽， 400 羽， 300 羽の計 1000 羽であった。地区 B は調査者 1 人で調べ，約 100 羽であった。

1982 年には, 1981 年と同様に地区 A, B に主な営巣地が形成されており, 規模は前年と比較 しやや小さかった。 7 月 13 日に地区 $\mathrm{A}$ の成鳥数を調查者 1 人で調べ，約 650 羽であった。地 区B の成鳥数は約 50 羽であった。

上述の地区 $\mathrm{A}, \mathrm{B}$ に定着していた個体は成鳥羽であるが，これらの全部が繁殖個体なのか， それとも，成鳥羽にはなっているが若齿の未繁殖鳥も含まれているかは明らかでない。

1983 年と 1984 年の繁殖期に地区 A に定着していた成鳥の個体数は調査されていないが, 1982 年と同じぐらいの成鳥が定着していたと思われる。ところで，本種の卵や雛は前述のよ うに見つけにくいという点を考慮に入れても, 卵雛の発見数は定着している成鳥数に比較する とかなり少ないのが事実である。このことから，定着している成鳥のなかには，成鳥羽にはな っているが，若秢で未繁殖の個体がかなり含まれているのかもしれない。 


\section{6. 七グロアジサシ Sterna fuscata}

営巣地域と環境

本種は島の中央部の海抜約 40-60 m の台地状の草地に主集団営巣地を 形成し, さらに, 海抜 $87 \mathrm{~m}$ 地点より西側の稜線部および島の東部, 海抜約 $40-48 \mathrm{~m}$ の稜線 部の狭い平坦地, 海岸線の所々にある岩石の累積していない草のはえた狭い平坦な場所などに 幾つかの副集団営巣地を形成している (Fig. 1, Fig. 4)。これらの集団営巣地域は，本島で繁 殖する他の 6 種の海鳥類の営巣地域と汪とんど重なっていない。

仲の神島で繁殖する海鳥類のなかで，おそらく繁殖個体数が最も多いのは本種であろら。繁 殖個体数が多く, 平坦地で集団営巣することと関連して, 台湾漁師によると思われる, 本種の 卵の大々的な採取がつい最近まで行われていたことは特筆すべきことであろう。

各年の繁殖状態の概況之個体数

Fig. 4-(1), 1975 年 8 月 27 日。本島の中央台地の平坦地には本種の成鳥も雛も観察されなか った。海抜 $87 \mathrm{~m}$ 地点より西側には 2 個所の集団営巣地が形成され, Feare (1976) による成長 段階 Stage 5-7 の幼鳥が見られたが，その数は100羽以下と少なかった。本種の卵採取の跡 はなかったが，おそらく繁殖期の初めに徹底的な卵採取があったと想像される。

Fig. 4-(2), 1976 年 6 月 23-25 日。中央台地の主集団営巣地に卵採取跡*が 2 個所に見られ, 抱卵中の多くの成鳥之泘化後 1 週間位までの Stage 1 の雛が見られた。西側の稜線の副集団営 巣地では，大部分の雛が Stage 3-4 であった。主集団営巣地では卵採取後に同じ地域で産卵 をしなおして繁殖が継続したらしく, 副集団営巣地に比較して繁殖段階はおくれていたと思わ れる。

Fig. 4-(3), 1977 年 6 月 28-30 日。主集団営巣地では雛の成長段階が Stage 1-3 で, 餒化 中のものから綿羽雊であるが駆け回るものまで見られ，抱卵中の成鳥も多く見られた。副集団 営巣地は稜線部に 5 個所, 海岸線に 5 個所が形成され, 副集団営巣地の雛の成長段階は, Stage 3 のものにほぼ一定していた。この調査中に, 主集団営巣地で雛 (幼鳥) 1132 羽, 副集団営巣 地で㱀（幼鳥） 864 羽に標識した。この羽数は営巣地にいた雛（幼鳥）の $90 \%$ 以上と思われ た。標識した雛 (幼鳥)の総数は 2000 羽に近く，さらに，多数の抱卵中の個体がいたから，総 繁殖番数は前年を上まわっていたと思われる。

しかし調查後の 7 月 31 日には，台風 7705 号が石垣島地方を通過し，西表島では最大瞬間風 速 $70 \mathrm{~m} / \mathrm{s}$ 以上を観測した。台風通過後の調査を行っていないが, 副集団営巣地のらち海岸線 の 5 個所は消失し, 稜線部の 5 個所は壊隇的な被害を受け，さらに主集団営巣地でもかなりの 幼鳥慗死が生じたと推察される(河野 他 1986)。

Fig. 4-(4), 1978 年 7 月 1-3 日。中央台地に卵採取跡があり, 海抜 $102 \mathrm{~m}$ 地点近くの集団営 巣地にも卵採取跡があった。抢そらく, 初めに中央台地に形成された主集団営巣地で卵採取が あり，その影響で後に集団営巣地が海抜 $102 \mathrm{~m}$ 地点付近に形成されたが，再度卵採取が行われ

*海鳥類の卵を食糧として利用する卵採取者は，胚発生の進んでいない産卵後数日内の卵を得るために， 抱卵の進んでいる集団営巣地の卵は大規模に取り除き，その地域に新たに産卵される卵を採取するか， あるいは, 事前に産卵期を調べておいて新鮮な卵を採取している。また, 真水や特定の濃度の海水に 採取卵を入れて, 卵の沈及方を目安に新鮮卵を選別している。本文中の「卵採取跡」とは，上述の上 らにして取り除かれた不要卵が一個所に大量に捨てられている所のことである。さらに，採取した卵 を一個所に集め，そこで卵を割って新鮮卵の中身のみを採り，残りの卵壳が捨てられている場合もあ る。 

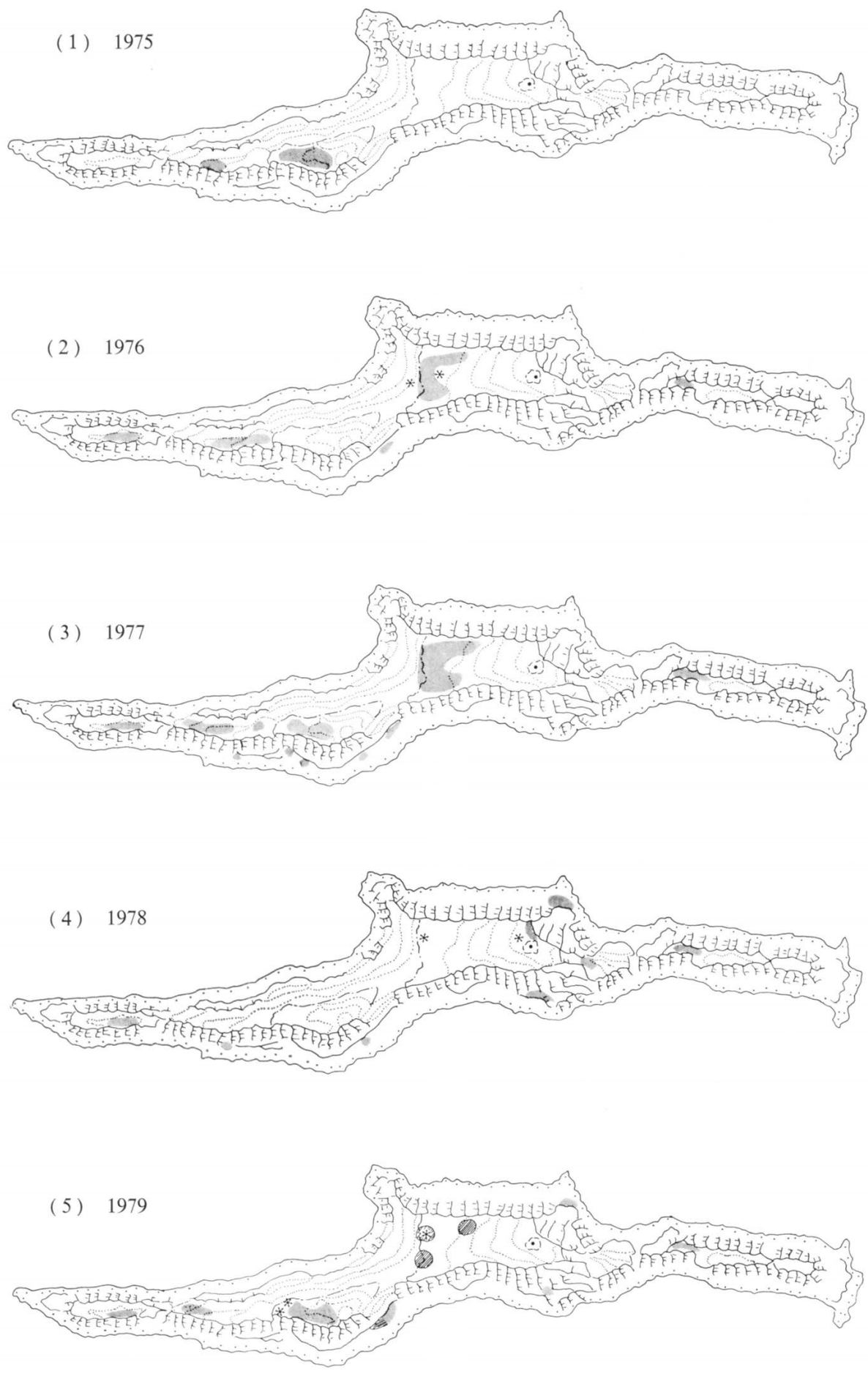

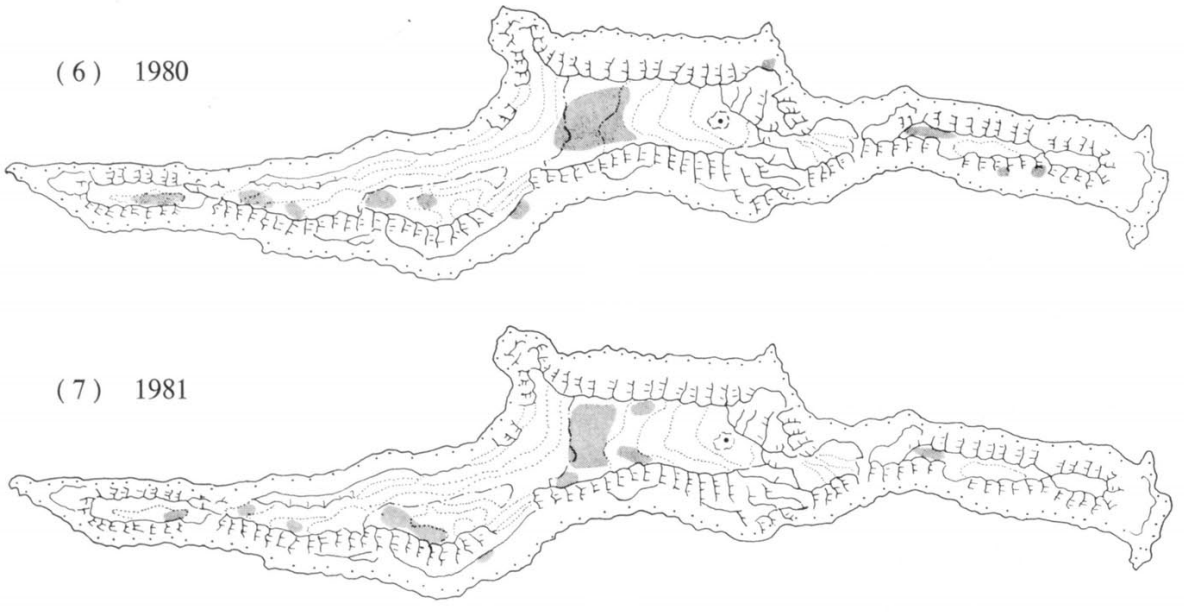

(8) 1982
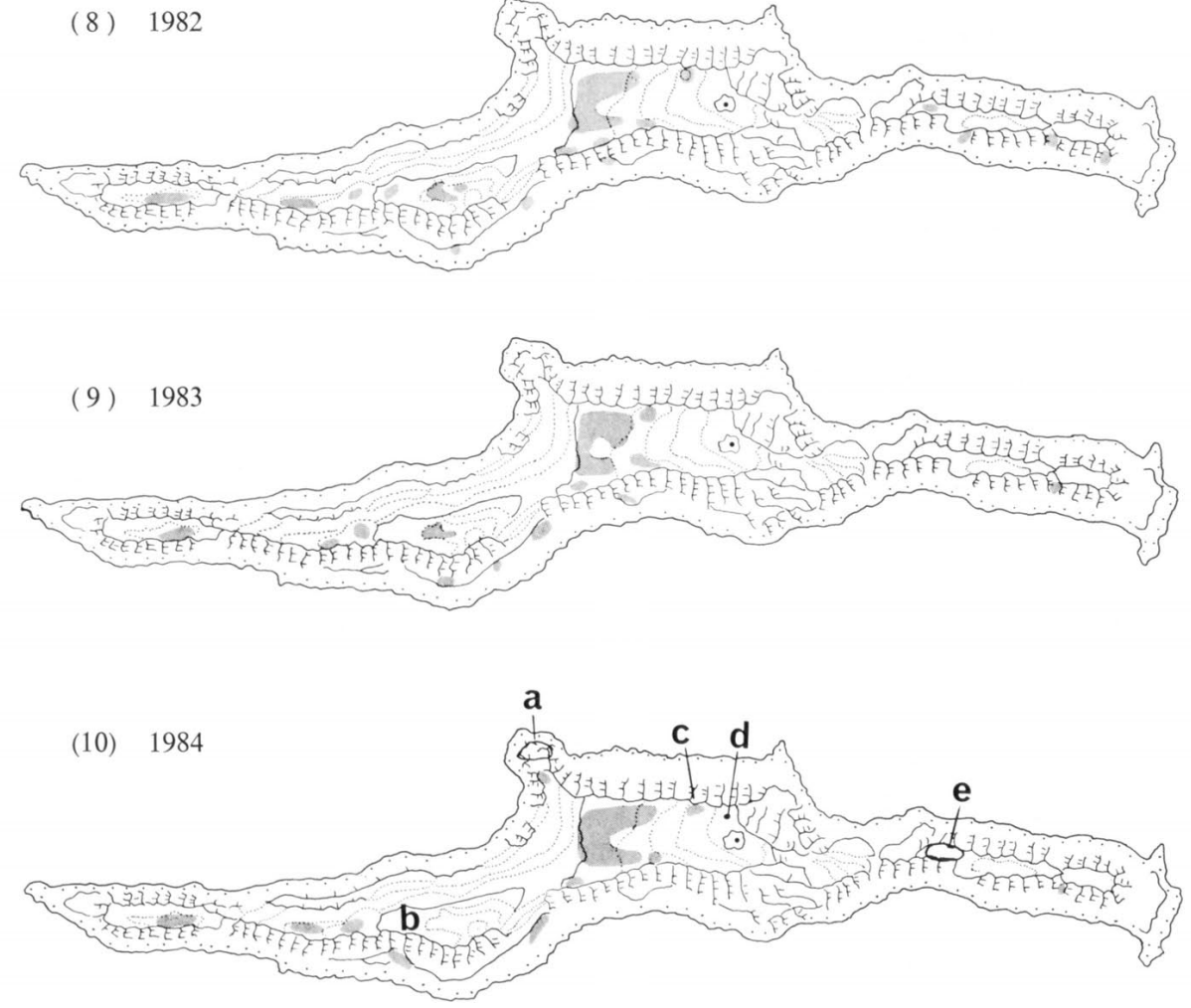

Fig. 4, (1)-(10). The locations of colonies of the Sooty Terns from 1975 to 1984 . The eggs were exploited by Formosan in 1975, 1976, 1978, and 1979; asterisk in the map shows a big heap of eggs and shells. (1) 27 August, 1975. (2) $23-$ 25 June, 1976. (3) 28-30 June, 1977. (4) 1-3 July, 1978. (5) 1-3 July, 1979. (6) 28-30 June, 1980. (7) 1-3 July, 1981. (8) 12-14 July, 1982. (9) JuneJuly, 1983. (10) 1984. 
たのであろら。2 度の卵採取は繁殖中断期間を長びかせ，繁殖を中止した番も多いと思われる。 副集団営巣地は 8 個所に形成され, この調査で標識された雛 (幼鳥) 499 羽は, この時期に営 巣地にいた全数にほぼ等しいと思われた。雛（幼鳥）の成長段階は Stage 4 までで, 抱卵中の 成鳥も少数見られた。卵採取による悪影響は甚大で，本年の 7 月 3-7 日に繁殖していた番数 は，おそらく500番前後であろう。

Fig. 4-(5), 1979 年 7 月 1-3 日。1979 年 5 月 14 日, 環境庁西表国立公園事務所の赤井氏は 中央台地に集団営巣地 (Fig. 4-(5) の斜線部) を観察している。同年 7 月 1-3 日にはその集 団営巣地は消失し，卵採取の跡が見られた。1978 年と同様に，主集団営巣地での 1 回目の卵 採取後, 集団営巣地は海抜 $87 \mathrm{~m}$ 地点付近に移動し, 再び 2 回目の卵採取があったと思われる。 このほかに稜線部に 3 個所, 海岸線地帯に 3 個所の副集団営巣地が形成されていた。この調查 中に標識された 281 羽の雛（幼鳥）は，この時期の全雊（幼鳥）数に近いものである。

Fig. 4-(6), 1980 年 6 月 28-30 日。卵採取跡はなく, 中央台地には主集団営巣地が形成され, 稜線部に 6 個所と海岸線地帯に 4 個所の副集団営巣地が形成されていた。しかし, 主集団営巣 地の雛の成鳥段階は Stage 1-4 とばらつきが大きく，抱卵している成鳥も見られたので，繁 殖初期に何らかの影響を受けたものと思われる。

Fig. 4-(7), 1981 年 7 月 1-3 日。中央台地に主集団営巣地（付近の小集団営巣地 3 個所を含 む)，稜線部に 5 個所と海岸線地帯に 1 個所の副集団営巣地が形成されていた。主集団営巣地 に見られた卵数と雛数の比は，およそ1:9で, 㮲の成長段階は大部分が Stage 4 かそれ以前の ものであった。各営巣地に日中留まっていた成鳥の総個体数は, 主集団営巣地に約 6000 羽, 副集団営巣地に約 500 羽であった。1981, '82, ’83 年の繁殖個体数については, 安部 他 (1986) で詳述した。

Fig. 4-(8), 1982 年 7 月 12-14 日。中央台地に主集団営巣地（周辺部の小集団営巣地 3 個所 を含も）が形成され，稜線部に 7 個所と海岸部に 6 個所の副集団営巣地が形成された。しかし， 8 月 9 日に台風 8211 号が来壟し, その後の被害調查で主集団営巣地内に雛 (幼鳥) 300 羽の死 体が回収された。副集団営巣地の小営巣集団地はいずれも壊隇的な被害を受けた（河野他 1986)。

台風 8211 号が来襲前の 7 月 12 日の調査では，日中に主集団営巣地に留むっていた成鳥の総 数は約 3500 羽，7 月 12-14 日の調査による副集団営巣地に日中留まっていた成鳥の総数は約 600 羽であった。 8 月 22 日の調査では, 主集団営巣地には抱卵中の成鳥はなく, 雛 (幼鳥) の 約 $80 \%$ は Stage 6 か 7 に成長し，その生残数は約 1800 羽であった。

Fig. 4-(9)，1983 年 6, 7 月。主副集団営巣地の形成状況は前年にかなり似ていた。主集団営 巣地の成鳥の個体数調査は 2 回行った。第 1 回目は, 大部分の成鳥が抱卵中の 6 月 11 日に行 い，第 2 回目は抱卵中の成鳥はすでになく，大部分の雛の成長段階が Stage 5 になっていた 7 月 19 日に行った。両日とも, 営巣地に日中留まっていた成鳥の総数は同じで, 約 2500 羽で あった。副集団営巣地の個体数調査は 7 月 12 日に行い, 日中留まっていた成鳥の総数は約 600 羽であった。

Fig. 4-(10)，1984 年。中央台地に主集団営巣地（周辺の小集団営巣地 2 個所を含む）とさら に離孔た場所に小集団営巣地が 1 個所形成され，稜線部に 3 個所と海岸部に 3 個所の副集団営 巣地が形成された。 
渡来から渡去までの概況 1984 年は，3 月 30 日から 10 月 17 日まで毎月ほぼ定期的に 渡島できたので, 本種の繁殖期の一般的な知見がさらに得られだ。しいし標識調査を主目的と していたので，繁殖生態に関する計画的な調查は行えなかった。ここでは，主に 1984 年の観 察資料を基に，本種の仲の神島への渡来から渡去までの概況を述べた。

セグロアジサシの繁殖島への渡来時期の行動の一つとして, 夜間に騒がしく鳴さながら飛来 すること，繁殖地やその周辺の上空で特徵のある声を発して夜間に騒ぐことがよく知られてい る（たとえば Chapin 1954, Ashmole 1963, Dinsmore 1972 など)。大仲 (1982) は石垣島地 方気象台の生物季節観測資料と大正 6 年の観察野帳にある「クイナ（方言名）は 3 月 6 日から 21 日の頃に, 夜間の降雨の際, 群集して南方海上より渡り来る鳥」といら記述から, このクイ ナはアジサシ類の一種であると示唆し, その渡来日は 3 月 5 日から 4 月 12 日, 平年値は 3 月 21 日としている。

最近の記録では，環境庁西表国立公園管理事務所長として石垣島に滞在していた百武充氏は 1981 年 3 月 2 日 0 時に石垣島登野城上空で鳴き続ける大群の声を録音した。後日,この録音を 聴かせていただき，仲の神島で繁殖期にも聴かれる本種の鳴声の一つであると確信した。

1983 年には, 3 月 14 日 23 時 43 分, 西表島西方沖 $\left(24^{\circ} 26.5^{\prime} \mathrm{N}, 123^{\circ} 30.6^{\prime} \mathrm{E}\right)$ において観測 中の東海大学丸 II 世 (702 t $)$ の上空に数羽が鳴きながら飛来した（澤本 1983，河野宛私信）。 また同月 21 日の早朝には, 西表島の網取と祖納の海岸上空に数羽が飛来した記録がある。

以下，1984 年の観察記録を調査日ごとに順に述べることにする。

3 月 27 日， 0 時 30 分一 2 時にかけて網取海岸上空に時々鳴きながら飛来する本種を記録。 3 月 30 日夜間, 石垣島地方気象台上空にも鳴きながら飛来し(慶世村 1984, 河野宛私信), 同 日の日中には仲の神島の上空を飛ぶ数 10 羽の本種が観察された。4月 20 日, 日中には営巣地 域に本種が降りた形跡はなかった。4 月 26 日, 中央台地にも稜線部にも本種が降りた形跡は 観察されなかった。しかし, 北に面した海岸線の中央部に張り出た広い平坦な岩場 (Fig. 4-(10) の地区 a) に約 200 羽の成鳥羽の個体が降りていた。この地域には, 繁殖期を通して成鳥羽の 群が観察されたが, ここは営巣地にはならなかった。これらの個体が繁殖鳥かそれとも非繁殖 かは確かめられなかった。

5 月 10 日, 主集団営巣地が例年形成される中央台地にはえる高さ $20-50 \mathrm{~cm}$ の草類（主に シバ類とカヤッリグサ類）を押しつぶすようにして座っていたり，あるいは草類の下に潜り込 むようにうずくまっている成鳥が日中に観察された。その個体数は繁殖盛期に比較するとまだ 少なかった。しかし, 周囲の丈の高い草類にも, 本種が降りて踏みつけた形跡が広範囲に見ら れたので，外国の繁殖地で知られているように（たとえば Ashmole 1963, Dinsmore 1972, Feare 1976)，すでに夜間には，さらに多くの個体がこの地域に降りていると思われた。主集 団営巣地内の北部では, 多くの個体がすでに抱卵中であった。一方, 中央から南部では, 北部 と同様に地上にうずくまっている成鳥が見られたが，産卵は始まっていなかった。同日，海抜 $87 \mathrm{~m}$ 地点の西側の棱線部 (Fig. 4-(10) の地区 b) にも成鳥が降りていて, その大部分が抱卵 中であった。このほかに, 棱線部に 3 個所, 海岸線に 2 個所に副集団営巣地が形成されてい た。Fig. 4-(10) に地区 $\mathrm{c}$ と として示した小集団営巣地は同日にはまだ形成されていなかっ た。

5 月 26 日, 地区 $\mathrm{b}$ の集団営巣地は消失し（おそらく, 調査の影響によると思われる), 新 
たに地区 $\mathrm{c}$ と に数 10 羽の成鳥が観察された。6 月 8 日, 地区 $\mathrm{c}$ には抱卵中の個体が見られ たが，地区dには産卵されていなかった。同日には，どの集団営巣地にも，まだ篗は見られな かった。

6 月 13 日の 21 時から 23 時末での約 2 時間, 主集団営巣地の繁殖進行状況を調べた。営巣 地に入っても鳴き騷いで飛び立つ個体はほとんどなく, 上空で少数が鳴くのみであった。営巣 地一面がまだ草類で被われたままで, 抱卵中の個体は草の下に隠れた状態か, 胸部から上半身 を草の下に突っ込んでいた。抱卵中の個体の尾羽を少し持ち持ち上げて, 卵や雛の有無を調查 したが，飛び立つ個体はほとんどいなかった。約 2 時間に多数の個体をこうして調査した結果， 餒化直後の雛之孵化後数日齢の雛が計 36 羽確かめられただけであった。つまり, 大部分の個 体が抱卵中で，孵化が始まったばかりの段階であった。なお，本種の1 腹卵数は 1 卵であるが， この調查中に，2卵を抱卵中の 2 羽が観察された。こ5いら例は, 隣からころがり込んだ余分

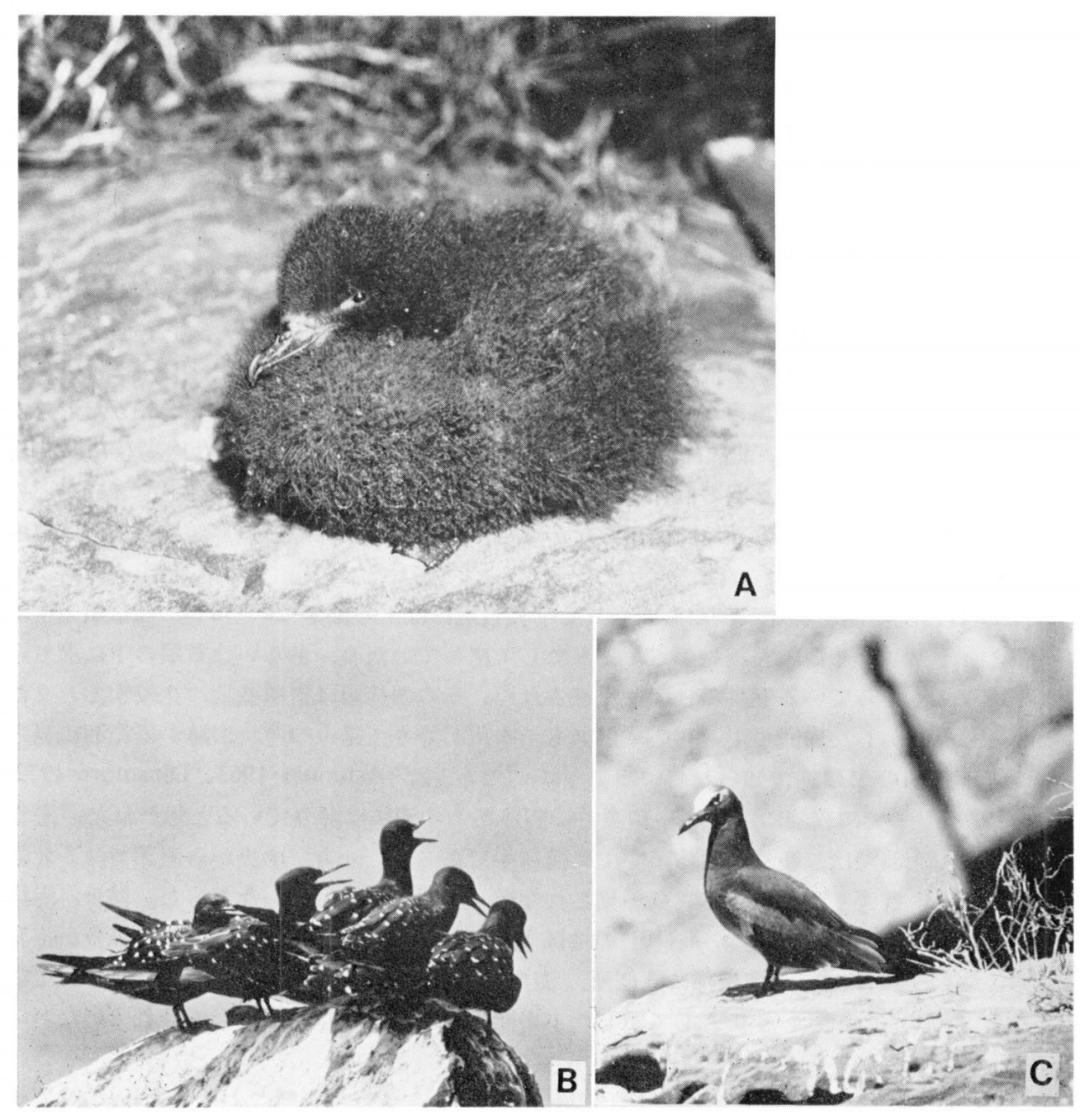



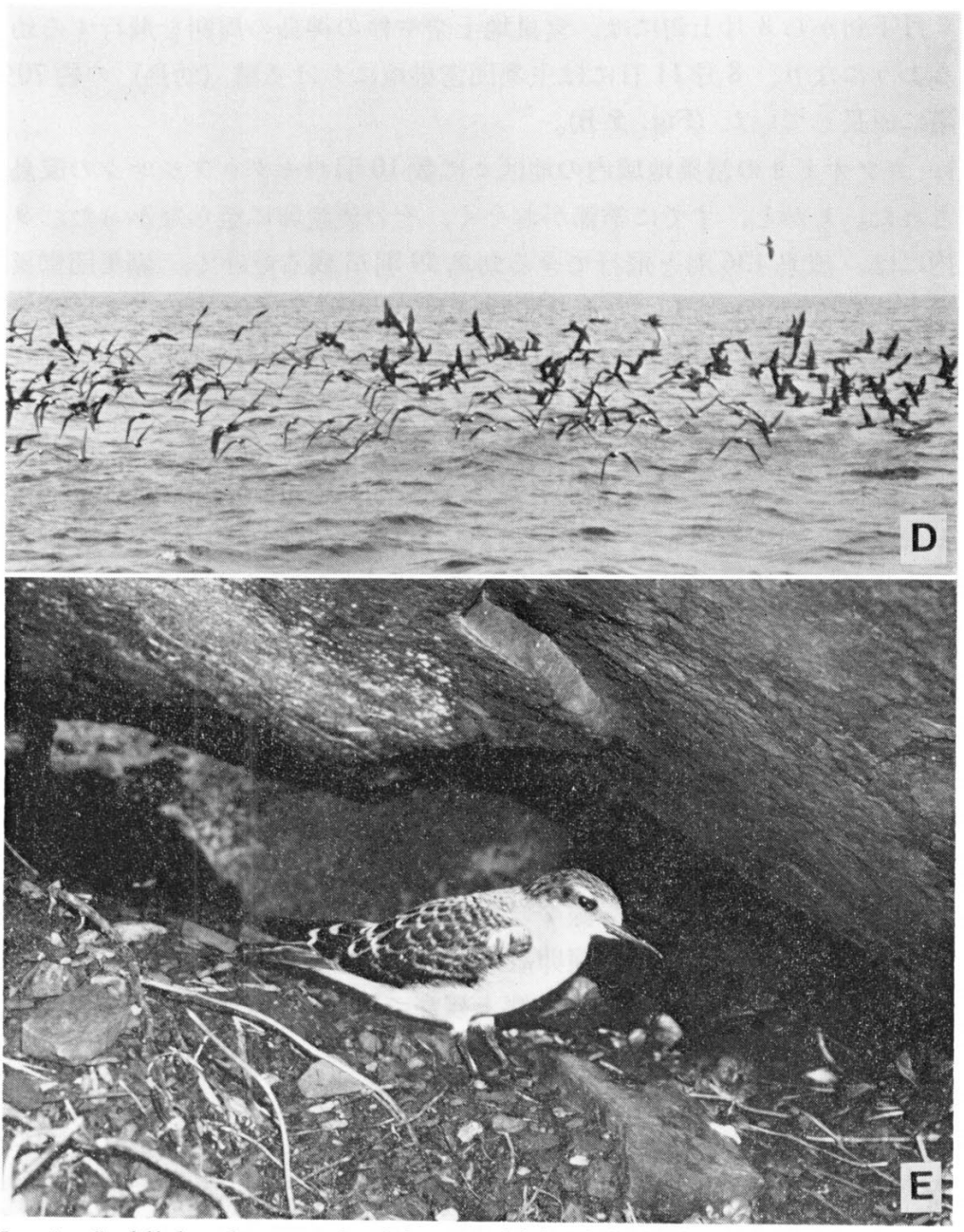

Fig. 5. A, flashlight photograph of downy chick of the Bulwer's Petrel. B, fledglings of the Sooty Tern. C, fledgling of the Brown Noddy. D, Brown Noddies gathering at adjacent sea of the breeding island before settling. E, flashlight photograph of fledgling of the Bridled Tern (H. Kohno).

の1卵を同時に抱卵していると考えられている (Serventy, Serventy, and Warham 1971)。

6 月 29 日, 主集団営巣地では, 抱卵中の個体もあったが, 大部分の番が育維期に入ってお り, 雛の成長段階は Feare (1976) によるStage 2-3 であった。7月19 日には, 主集団営巣 地の雛の成長段階は Stage 2-5 で, その大部分は Stage 5 であった。この頃には, 営巣地の 草類が枯机て, 遠距離からでも本種の成鳥と雛（幼鳥）の判別ができる状態になった。同日に は，地区 $\mathrm{d} の$ 集団営巣地は完全に消失していた。

本年の繁殖期には，各営巣地に日中留まっていた成鳥の総数を調査していない。1981，'82， '83 年の調査および 1985 年の調査結果と比較してみると, 本年には主集団営巣地にはおよそ 3500一4000 番が繁殖していたと思われる。 
その後, 7 月下旬から 8 月上旬には, 営巣地上空や仲の神島の周囲を飛行する幼鳥が海上か ら観察されるようになり，8月 11 日には主集団営巣地にお打雛（幼鳥）の約 70\% 以上が飛 行できる段階に成長していた (Fig. 5-B)。

8 月 23 日, カツオドリの営巣地域内の地区 $\mathrm{e}$ に数 10 羽のセグロアジサシの成鳥が降りてい るのが観察された。しかし，すでに季節がおそく，その後産卵に至らなかった。9月6日, 主 集団営巣地内には, 成鳥 136 羽と飛行できる幼鳥 59 羽が残るだけで, 副集団営巣地には 1 羽 の成鳥も幼鳥も観察されなかった。9月27日, Fig. 4-(10) の前述の地区 a に成鳥 5 羽と幼鳥 3 羽が観察された。主集団営巣地は 9 月中旬頃から再び草で被わ始め, 10 月には, それま で露出していた部分も草類で被われるようになった。10月17日，12月14日の日中の調査で は，本種は全く観察されなかった。

以上の 1984 年の調查結果と本種の抱卵日数 27-30日 (Ashmole 1963, Feare 1976) から, 本年の繁殖期は次のように進行したと推察される。(1) 3 月下旬頃に仲の神島周辺に渡来し, (2) 稜線部と海岸線の小集団営巣地, 島の中央部台地の主集団営巣地域の一部に, おそらく 5 月初め頃には着陸が始まり, 徐々に中央台地の営巣地を拡大した。(3) 5 月 10 日前から産卵 が始まり，(4) 餒化開始はおよそ6月 5-10日の間であった。(5) 雛（幼鳥）のうち，成長の 早いものは 7 月下旬に飛行可能な段階になり，(6) 成鳥, 幼鳥とも 9 月下旬にはほぼ総てが島 から渡去した。

7. クロアジサシ Anous stolidus

営巣地域と環境本種は, 仲の神島のほぼ全周囲の断崖上縁部や岩棚, 北側の海岸線に落 ちる草付きの急斜面にある岩場や海岸線の岩石累積帯上部にある岩場の岩上や棚状部などに少 数の小石片を置いて営巣している。1 腹卵数は 1 卵である。

渡来から渡去までの概況渡島および海上観察によって得られた 1984 年の本種の渡来か ら渡去までの概況は次のとうりであった。

1984 年 3 月 30 日の日中には, 西表島西端一本島間の海上と営巣地域にクロアジサシの姿は 見られなかった。4 月 20 日には, 本島の北方約 $1 \mathrm{~km}$ の海上で, 東西方向に約 $500 \mathrm{~m}$ の帯状 にのびる群をなして浮遊する約 600 羽のクロアジサシを観察した。この浮遊群は採食中のもの ではなく, ボートで近寄ると, 飛び立つが約 200-300 m 移動すると海面に降りる行動を繰り 返した。本種の営巣地になる岩場一帯を日中調査したが，まだ 1 羽も着島しているものはなく, 着島の証拠となる白い翼の跡も見られなかった。これょり早く 4 月 13 日に仲の神島周辺海域 を訪れたダイバーが，上述のものと同様の行動を示した本種の群を観察した確かな記録がある

(河野宛私信)。さらに, 1980-'84 年の 4 月中旬頃には, 西表島西部のウナリ崎から八重目崎 の沖合約 $10 \mathrm{~km}$ 以内の海域において, カッオ, スマなどの回遊魚群に追い上げられた小魚を 捕食する約 30-200 羽の本種の群が何度も観察されている (Fig. 5-D)。

1984 年 4 月 26 日の日中には, 本島全域にひろがる本種の営巣地の約半分を踏査し, かなり の成鳥が岩棚に観察された。しかし，卵は見つからなかった。5月10日に初めて少数の番が 産卵していた。 5 月 26 日には，多くの番が抱卵に入っていたが，まだ篧は 1 羽も観察されな かった。6月 13,14 日には, 餒化後間もない雛が少数初めて観察され, 大部分の番は抱卵中 であった。それ以後，7月20日までの調査では，巣から離れる段階に育った雛（幼鳥）は観 察されなかった。7 月22，23 日には，本島の周囲を低速で回る調査用ボートの船尾を5 羽の 
幼鳥が追い, 各営巣地の岩場でも飛行する幼鳥が観察された。けれども, 同日には, まだ抱卵 中の成鳥も多数観察されている。なお，本種の抱卵日数は 32-35 日 (Watson 1908) である。

1984 年 9 月 $6 ， 7 ， 11 ， 12$ 日には，20 時一03 時の間に本種の標識調查を行った。この時期 には, 汪ぼ総ての雛 (幼鳥) がすでに「巣立」っていた。そして, 海岸線の岩石累積帯のなか の比較的大きな岩上に成鳥と「巣立幼鳥」が集まって眠っている場面が幾つも観察された。一 方，営巣地の岩棚にいる個体数は育雛期にくらべて減少していた。1983 年にも， 8 月 29, 30 日と9月 1，2 日9夜間調查中にこれと同じょうな状況が観察されている。

1984 年 9 月 27 日には成鳥も「巣立幼鳥」も多数観察されたが，10月 17 日には本島の中央 部より西側の北に面した海岸線の岩石累積帯に, 成鳥か幼鳥か判別のつかない約 50 羽が観察 されただけだった。その後, 11 月は荒天時化のために渡島できなかった。12月14日の調查で は，本種は観察されず，すでに渡去した後であった。

雛の羽色型について 世界各地のクロアジサシの綿羽雛について, 淡色型から暗色型, そ の中間型など多型が知られている (Dorward and Ashmole 1963)。暗色型といわれるものは, 全身の綿羽が一様に褐色を带びた黒色, 淡色型は一様にすすけたよらな白色である。

本島で繁殖するクロアジサシの雛は，これまで調べた限り，この淡色型に分類できるもので あった。

\section{繁殖鳥以外の海鳥類の記録}

前章で述べた仲の神島で繁殖する 7 種の海鳥以外に，仲の神島とその周辺海域および西表島 西部のウナリ崎から八重目崎の沖合約 $10 \mathrm{~km}$ 以内の海域から次の 14 種の海鳥が記録されてい る。

1. アカアシミズナギドリＰuffinus carneipes

1983 年 7 月 28 日, 仲の神島と西表島西部八重目崎との中間海域で, 約 150 羽のクロアジサ シ, 約 20 羽のオオミズナギドリと少数のカッオドリの混合群が採食するなかに， 3 羽の本種 が観察された。

本種とハシボソミズナギドリは, 渡りの季節には本州から北海道の沿岸海域に普通に大群が 分布しているが，八重山諸島の近海は両種の渡り（北方回遊）のコースから外れているのであ ろら，きわめて稀である。

2. アカオネッタイチョウ Phaethon rubricauda

本種は, 1975 年一1984 年の調査期間中に，毎年 $2-8$ 羽が観察されている。1982 年 7 月 4 日に, 海抜 $102 \mathrm{~m}$ の頂上部南側の断崖の岩棚に 1 羽が降りていた 1 例以外, 観察例は総て飛行 個体である。仲の神島に抢ける本種の最も早い観察記録は1984 年 4 月 26 日，おとい記録は 1975 年 8 月 27 日である。

3. シラオネッタイチョウ Phaethon lepturus

本種はこれまで 3 回記録されている。いずれも 1 羽で飛行中の観察記録で, 明らかに前種よ り稀である。観察年月日は 1977 年 6 月 28-30日, 1978 年 7 月 $1-3$ 日, 1980 年 6 月 28-30 日である。

4. アオッラカッオドリ Sula dactylatra

本種は, 1980 年, 1982 年, 1983 年, 1984 年に記録されている。特に 1983 年 7 月 12 日ー11 
月 10 日には， $1-3$ 羽の成鳥羽の個体が 6 回 ( 7 月 12 日と 28 日に 2 羽， 8 月 3 日と 8 日に 1 羽，10月 17 日に 3 羽，11月 10 日に 2 羽）観察されている。この間，同じ個体が定着して いたかどうかは明らかでない。

11 月 10 日には, 次に述べるような行動を観察した。11 時 30 分頃, カッオドリの営巣地域 (Fig. 2 の地区 B) において，2羽の成鳥羽の本種を見つけたので，およそ $10 \mathrm{~m}$ 離れた岩陰か ら観察した。その営巣地には, カッオドリの成鳥 10 数羽と巣立幼鳥 2 羽が降りていたが, 本 種の 1 羽が，そこにあるすでに使われていないカツオドリの巣に座り，その巣の横の岩上には 他の 1 羽が降りていた。Fig. 2 の地区 A と B の上空には, 多数のカッオドリの成鳥が飛行し ており，約 5 分ほど観察しているらちに岩上の 1 羽は飛び立ち，上空を旋回しはじめた。この 時, 巣に座っていた個体は, 尾羽を少し立て, 両翼を閉じたまま上方へもちあげるよらに膨ら ませ，頸部と嘴を垂直に伸ばして上空を指し，飛行個体を指し示すような動作 (Sky-pointing) を約 5 分間に何度か断続的に行った。飛行個体はそのまま本島と周囲の海上を旋回し続け，さ らに 5 分後には巣上の個体も飛び立った。その巣内には産卵されていなかった。

Dorward (1962) は，アセンション島において，本種の Sky-pointing display 観察してい る。それによると, Sky-pointing は集団繁殖地の大部分の成鳥が抱卵期か育篗期に入っている 時期に観察され，番になっていない雄が，営巣地域内を歩き回る番になっていない雌に対して よく行らディスプレイ行動で, また, 上空を飛行中の個体に対しても行ったと述べ, 番を形成 していない鳥でこの行動を示す鳥は若龄個体であろうと推察している。

上述の記録以外に仲の神島にお拈ける本種の確かな記録はない(この点についてはアカアシカ ツオドリの項に記した)。

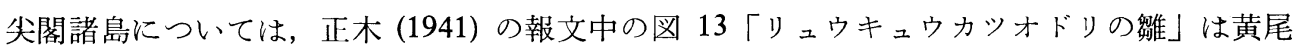
島で撮影されたもので, これは本種の幼鳥と成鳥である。同諸島には現在も少数が繁殖してい るようなので, 仲の神島でも今後本種の繁殖の可能性があろら。

5. オオグンカンドリ Fregata minor

6. コグンカンドリ Fregata ariel

仲の神島上空を飛行中のオオグンカンドリ 1 羽 (1984 年 9 月 6-9 日), コグンカンドリ 1 羽 (1976年 6 月 23-25日) 同 2 羽 (1979年 7 月 1-3 日), 種不明の 1 羽 (1983 年 8 月 21 日) の記録がある。

7. アカエリヒレアシシギ Phalalopus lobatus

1984 年 4 月 26 日, 仲の神島一西表島間の海上で浮遊中の 1 羽を観察した。このほかの八重 山諸島での記録は，1978 年 4 月上，中旬に西表島の船浮湾で 6 回（庄山 1981, 河野宛私信）, 1978 年 4 月 1 日に与那国島, 1982 年 4 月 3 日に石垣島（八重山野島の会 1982）などがあり, いずれも 4 月上，中旬に観察されている。

8. トウゾクカモメ Stercorarius pomarinus

1984 年 7 月 11 日, 西表島西部の上原海岸で 1 羽の死体が収得された。この個体は淡色型で, 尾羽が成鳥羽になっていない若龄個体であった。

9. ズグロカモメ Larus saundersi

1980-1983 年の $4 ， 5$ 月に西表島西部沖合で採食するクロアジサシの群に混じっている数羽 が何度か観察されている。沖合における記録はむしろ珍しいものであろら。八重山野鳥の会 
(1982) によれば，八重山諸島からの記録として，1976 年 1 月に石垣島での観察記録がある。 10. オオアジサシ Sterna bergii

西表島, 石垣島周辺海域への本種の渡来は 4 月中旬から下旬で, 夏期には海上で普通に観察 される。しかし仲の神島では, 1982 年 8 月 18 日に, 海抜 $102 \mathrm{~m}$ 地点の上空を旋回飛行する 2 羽を観察し, 同年 8 月 22 日には, 本島一西表島間の海上を南南東へ飛行する 12 羽の群を観察 したにすぎない。

尖閣諸島での本種の繁殖はすでに知られている。上述の上うに, 西表島, 石垣島周辺の海域 には夏期に普通に棲息しているのに繁殖記録がないのは，本種の繁殖に適した環境の一つであ る比較的広い砂地の海岸とか平坦な岩磐のひろがる環境で，しかも人の出入のない条件の場所 が無いからかもしれない。

\section{1. ベニアジサシ Sterna daugallii}

1980-1984 年の観察では, 毎年 5 月頃に西表島西部沖合で採食するクロアジサシの群に混 ざる数羽が観察されている。本種の繁殖期は比較的おそいので渡り途中のものであろう。6, 7 月中は本調查地内では稀にしか観察されない。8 月下旬から 9 月上旬頃, エリグロアジサシ の繁殖する西表島網取湾の軍艦島で, エリグロアジサシの成鳥と独立幼鳥の群の中に, 本種の 成鳥と幼鳥（合計で 5 羽以内のことが多い）がたびたび観察されるようになる。

本調查地に近い本種の繁殖地としては, 石垣島周辺の小さな属島が以前から知られている。 1982 年 7 月 15-20日に, 上述の石垣島周辺の既知の本種の繁殖地を含む, 石垣島, 竹富島, 小浜島, 黒島, 西表島のエリグロアジサシの繁殖する 14 個所の属島を調査したが, 本種は繁 殖していなかった。

沖縄, 石垣島などの本種の繁殖地周辺での観察では, 繁殖期の本種はよく発達した珊瑚礁原 とその周辺部の海域内で主に採食している。そして, 珊瑚礁の発達した沿岸に幾つかの小島が あるような環境を繁殖地として選好している。従って, 仲の神島のような珊瑚礁原が狭い, 沖 合の孤島は本種の繁殖地になりにくいのであろう。

\section{2. エリグロアジサシ Sterna sumatrana}

日本鳥学会（1974）の目録には，仲の神島における本種の繁殖が記されているが，すでにこ の点については, 安部・真野 (1980) で1975-1980 年までの時点での「仲の神島における本種 の繁殖」を疑問視しておいた。

その後も, 1982 年 6 月 4, 9 日, 1984 年 6 月 4 日に, 仲の神島の周囲を飛行するか, 周囲 の海上で採食するクロアジサシの群に混じっている 1 羽か 2 羽の本種が観察されたにすぎない。

本種は八重山諸島の珊瑚礁原の発達している属島で繁殖し, 仲の神島に最も近い繁殖地は, およそ $20 \mathrm{~km}$ 離れた西表島網取湾のユシキ離島と軍艦島である。網取湾付近において 19821984 年に得られた断辺的な観察記録によれば，本種の渡来から渡去までの概況は次のよらで ある。

5 月上, 中旬頃, 西表島西部の沖合で採食するクロアジサシを主とした採食群に 10 羽以内 の本種が混じっているのをたびたび観察している。この頃, 網取湾では本種の姿はまだ観察さ れていない。5 月下旬になると, 上述の繁殖島に降りている姿を見るようになり, 徐々に羽数 が増觉ていく。

例えば，軍艦島では，1982 年 5 月 28 日に 3 羽, 30 日に 6 羽, 6 月 1 日に 10 羽, 1983 年 5 
月 22 日に 3 羽， 6 月 7 日に 10 羽以上， 1984 年 5 月 22 日に 4 羽が観察された。その後の繁殖 個体の定着状況は調査されていないが，6月下旬には各年ともに80-100 羽となった。

1982 年には, 7 月 15 日 17 時に人が近づいたために飛び立った羽数を 4 回数えたところ平均 89 羽であった。当日の営巣状態は 27 巣 37 卵 7 雛 ( 1 卵 10 巣, 2 卵 12 巣, 3 卵 1 巣, 1 雛 1 单, 2 雛 3 巣) であった。この 4 巣分の計 7 雛は, いずれも同程度の成長段階で餒化後数日齡 と推定される綿羽雛であった。7 月 24 日の営巣状態は 31 巣 23 卵 27 雛 (1 卵 5 巣, 2 卵 8 巣, 1 卵 1 雛 2 巣, 1 雛 6 巣, 2 雛 10 巣) であった。 8 月 16 日 22 時の軍艦島の営巣地には, 飛 行するのもまもない成長段階の幼鳥 3 羽だけが残り, 営巣地から離れた岩礁に多数の幼鳥之成 鳥が降りていた。9月10-12 日には，北寄りの強風に上る荒天時化の網取湾内で，採食する 20 羽の成鳥と幼鳥を観察したが, 翌 13 日には軍艦島と周辺海域に本種の姿はなく, 渡去した と思われた。しかし, ユシキ離島には成鳥 2 羽と幼鳥羽の個体 1 羽が残り, 湾内とその周辺海 域で 10 月 21 日まで採食を続けていた。この 10 月 21 日が本種の最もおそい観察記録である。

仲の神島における本種の観察日はどれも6月上旬で, 上述の繁殖期の概況によれば，この頃 は営巣地への定着期に当っている。営巣地で観察される成鳥がすべて繁殖鳥であるとは言えな いが (例えば, 1982 年の繁殖期の成鳥数 89 羽, 観察最大巣数 31 巣), 抱卵, 育觹時期の本種 は, 湾内や珊瑚礁原縁などの岸近くで採食し, 渡来期のような沖合での採食が今までに観察さ れていない。これらのことから，仲の神島周辺海域における6月上旬の観察記録は, 本種が営 巣地を捜していたものとも推察できるだろら。しかし本種も, すでに述べたベニアジサの場合 と同様の環境で繁殖する傾向が強いので, 仲の神島は本種の繁殖地としては不適である。

13. ウミスズメ Synthlioboramphus antiquus

14. カンムリウミスズメ S. wumizusume

本調査域および八重山諸島からの両種の公表記録は下記のようにきわめて少ない。

ウミスズメについては，(1) 宮古島, 1908 年 12月, (2) 石垣島, 1925 年 1 月（以上, 清棲 1978)。鄭作新（1978）によれば，本種は福建海峡，台湾では冬鳥である。

カンムリウミスズメについては，（3）西表島上原海岸, 1978 年 11 月 27 日, 漂着死体, (4) 石垣島, 1979 年 1 月 24 日, 漂着, 保護後に死亡 (以上, 八重山野鳥の会 1982)。さらに, 小 林・張 (1981) によると「1973 年 1 月 1 日，台北県八斗付近の海上で $5 ， 6$ 羽が目撃されたが， この中の 1 羽が海岸に漂着し, 標本として[台湾の] 東海大学に保存されている」。

次の記録は本報告での追加記録である。ウミスズメ—(5) 西表島上原, 1984 年 3 月 1 日, 漂着死体, 夏羽。カンムリウミスズメ—(6) 西表島上原, 1980 年 12 月 29 日, 漂着, 保護後 に死亡。種不明のもの一-(7) 西表島網取, 1979 年 12 月 14 日, 漂着死体, 頭部無く, 種の同 定できず，（8）西表島サバ崎，1983 年 1 月 27 日，珊瑚礁原縁にて 1 羽を観察 (河野) したが, 条件悪く種の同定できず。

(3), (4)のカンムリウミスズメは, いずれも喉は下嘴のつけ根まで白色, 後頭から後頸は黒 灰色, 眼の上から後頸に約 $13 \mathrm{~mm}$ 以下の白色の細長い羽毛がまばらには光, 前額から頭央に かけて約 $20 \mathrm{~mm}$ の黒色の冠羽がはえていた。

これらの両種の記録は, (5) 以外は冬期のもので, 漁師からの聞き取りによれば, ウミスズ 又類は冬期に南部琉球海域にかなり渡来しているようである。両種の繁殖地は完全に明らかに なっていないとはいえ，各年の海況によって，特に冬期の分布は影響を受けると考えられるの 
で, 南西諸島およびその周辺海域における両種の海上での分布を明らかにするためにはカンム リウミスズメの第 1 回冬羽, 成鳥冬羽の特徴の解明が必要であろう。

\section{む す び}

亜熱帯ないし熱帯の大洋の中央部に位置する島々に比較して，仲の神島はその位置上，海洋， 気象の季節的变化を受けやすいからと思らが，本島で繁殖していた 7 種の海鳥は，いずれも繁 殖期のみに本島に定住し，12 個月周期で繁殖していた。

セグロアジサシについては，世界各地の繁殖地における繁殖期と繁殖周期がよく知られてい、 る (Ashmole 1963a, Chapin 1954, Chapin and Wing 1959)。仲の神島のセグロアジサシと クロアジサシは夏期の同時期に 12 個月周期で繁殖している。倉田・金子 (1982) は, 西之島に おいてはセグロアジサシとクロアジサシが 1 月と 6-7 月に 2 回産卵すると報じている。日本 国内にあるこの 2 島におけるこれら 2 種の繁殖生態の詳しい比較は興味ある研究課題である。 しかしながら，仲の神島で繁殖する両種を含むどの種についても，その生活様式一般の計画的 な観察, 採食海域の探索, 繁殖と換羽の関係 (Ashmole 1963a, b, Dorward and Ashmole 1963）などその他多くの問題が，全く手がつけられずに残されている。

仲の神島で繁殖個体数が最も多いと思われるセグロアジサシの繁殖個体群は，ここ10 年間 については，おそらく1 万番を越えないであろう。Fig. 2-(1)-(10) に示したように，年によ り台湾漁師によると推察される本種の卵の大規模な採取があり, きわめて不安定な状態である。 繁殖期に仲の神島に定住しているセグロアジサシとおそらくマミジロアジサシの成鳥の個体数 は, 台湾周辺の小島, 尖閣諸島など両種の繁殖地における各年の卵採取や軍用上の島の利用に よる攪乱状態の影響を受けて変動しているのかもしれない。

卵の採取の悪影響だけを考えれば，平坦な環境に集団で営巣するので，その卵が採取されや すいセグロアジサシにくらべると，本島のほ注全域の崖や岩場の棚状部に小集団で営巣してい るクロアジサシの繁殖状態は毎年はるかに安定しているであろら。

幸い仲の神島には, 海鳥類の繁殖成功率を大きく左右すると思われるような捕食動物は棲息 していないので, 採食海域, 日周活動, 営巣場所, 繁殖成功率と若㱓未繁殖鳥の割合の年变化 など繁殖生活全般を特別調査区を設けて各種について詳しく調査する価值がある。

本報で記した知見の一部は, 山階鳥類研究所・標識室が環境庁から受託した鳥類標識調査中 に得られたものである。本島での標識, 回収記録については,この 10 年間にかなり興味深い 資料が集まりつつあるので別に報告されるであろら。

仲の神島の全汀線部の岩石が排油によって著しく污されているとはいえ，この島は国内では 無類の美しい海鳥の集団繁殖地である。本島が観光地化するのを防止し, 積極的な保全対策が とられることを期待したい。

\section{謝辞}

その結果の一部を本報中にも記した標識調査に従事され, 本報の調査に協力して下さった山 階鳥類研究所・標識研究室の方々と地元の方々, いろいると便宜を与えられた西表国立公園管 理事務所の職員の方々に扮礼申し上げる。さらに, 河野にこの調查の機会を与えられた東海大 学海洋研究所西表分室の職員の方々と学生諸氏に深謝の意を表する。 
引用文 献

安部直哉, 真野 徹 1980。 日本におけるマミジロアジサシの繁殖. 山階鳥類究研所研究報告 12: 183191.

安部直哉, 真野 徹, 久見勝盛, 山本 晃 1982。、ミシシロアジサシの新繁殖地と体の計測值. 山階鳥類 究研所研究報告 14: 72-76.

安部直哉, 河野裕美, 真野 徹 1983. 仲の神島で繁殖するセグロアジサシの個体数と雛(幼鳥) 数の推定. 山階鳥類究研所研究報告 18: 28-40.

Ashmole, N. P. 1963a. The biology of the Wideawake or Sooty Tern Sterna fuscata on Ascension Island. Ibis $103 \mathrm{~b}:$ 297-364.

Ashmole, N.P. 1963b. Molt and breeding in populations of the Sooty Tern Sterna fuscasa. Postilla 76: 1-18.

Berger, A. J. 1972. Hawaiian Birdlife. 270 pp. Univ. Press of Hawaii, Honolulu.

Chapin, J.P. 1954. The calendar of Wideawake fair. Auk 71: 1-15.

Chapin, J. P., and Wing, L. W. 1959. The Wideawake Calendar, 1953 to 1958 . Auk 76: 153-158.

鄭 作新 1976. 中国鳥類分布名録. 第 2 版, 1218, 科学出版社.

Diamond 1976. (S. Cramp edt., Handbook of the birds of Europe, the Middle East, and North Africa, Vol. IV, 1985 より).

Dorward, D. F. 1962. Behaviour of Boobies Sula spp. Ibis 103b: 221-234.

Doward, D. F., and Ashmole, N. P. 1963. Notes on the biology of the Brown Noddy Anous stolidus on Ascension Island. Ibis 103 b: 447-457.

Feare, C. J. 1976. The breeding of the Sooty Tern Sterna fuscata in the Seychelles and the effects of experimental removal of its eggs. J. Zool. Lond. 179: 317-360.

藤岡義三 1978. 琉球大学探検部発行「中の神島調査報告」pp. 11-13.

藤村 ヒ 1985. (安部宛の私信).

Hulsman 1974, 1977. (S. Cramp edt. 前掲書より).

石丸明弘 1980. 沖縄西表島網取気象観測報告. 東海大学海洋研資料. 2: 3-15.

喜舍場永珣 1953. 八重山歴史 pp. 407-409, 国書刊行会.

慶世村清記 1984. (河野宛私信).

清棲幸保 1978 . 日本鳥類大図鑑。講談社。

小林桂助, 張 英彦 1981. 台湾鳥類図鑑. $239 \mathrm{pp}$, 前田グラフィック・アーツ.

河野裕美, 安部直哉, 真野 徹 1986. 台風 8211 号による仲の神島のセグロアジサシの整死について。山 階鳥類究研所研究報告 18: 41-50.

倉田洋二，金子 博 1982. 西之島探索行。 アニマ9月号：6-12.

黒島宽松 1964，仲ノ神島. 琉球新報 1964 年 6 月 14-16日.

正木 任 1941 . 尖閣群島を探る. 採集と飼育 3: 102-111.

宮島幹之助 1900. 沖縄県下無人島探検談. 地学雑誌 12: 585-596.

日本鳥学会 1974. Check-list of Japanese Birds. Fifth and revised edition および和文版. 学習究研 社.

西村 真 1984。 (河野宛私信).

小川三紀 1906. 台湾綿花島にて獲たる数種の鳥類. 動物学雑誌 18: 125-131.

大仲浩夫 1976. 海鳥の楽園. 仲の神島. 野鳥 41: 20-24.

大仲浩夫 1982. 戦前の野鳥資料. 八重山野鳥の会 10 周年記念誌：15-17.

Serventy, D. L., Serventy, V., and Warham, J. 1971. The Handbook of Australian Sea-Birds: 225-227.

澤本彰三 1983。(河野宛私信).

Shelton, P. 1977. (S. Cramp and KEL Simmons, edt., Handbook of the birds of Europe, the Middle East, and North Africa, Vol. 1, 1977 より).

高良鉄夫 1970. 琉球仲の神島の海鳥. 山階鳥類研究所報告 6: 188-194.

Watson, J. B. 1908. The behaviour of Noddy and Sooty Terns. Tortugas Laboratory of Carnegie Inst., Washinton 2: 187-225. (Serventy, Serventy, and Warham 1971, 前掲書より).

八重山野鳥の会 1982.10 周年記念誌. 八重山野鳥の会. 
山階鳥類研究所標識究研室 1978. 鳥類観測ステーション報告. 昭和 51 年度 pp. 205-219.

山階鳥類究研所標識研究室 1980。鳥類観測ステーション報告, 昭和 54 年度 pp. 109.

河野裕美: 干907-15 東海大学沖縄地域研究センター. 沖縄県八重山郡竹富町崎山 165.

安部直哉: $\bar{T} 228$ 神奈川県相模原市旭町 22-21, 柳下荘.

真野 徹: T470-12 愛知県豊田市和会町上屋敷 33 (元山階鳥類究研所標識研究室). 